Prepared in cooperation with the Arkansas Natural Resources Commission and the Arkansas Geological Commission

\title{
Status of Water Levels in Aquifers in the Nacatoch Sand of Southwestern and Northeastern Arkansas and the Tokio Formation of Southwestern Arkansas, February 2005
}

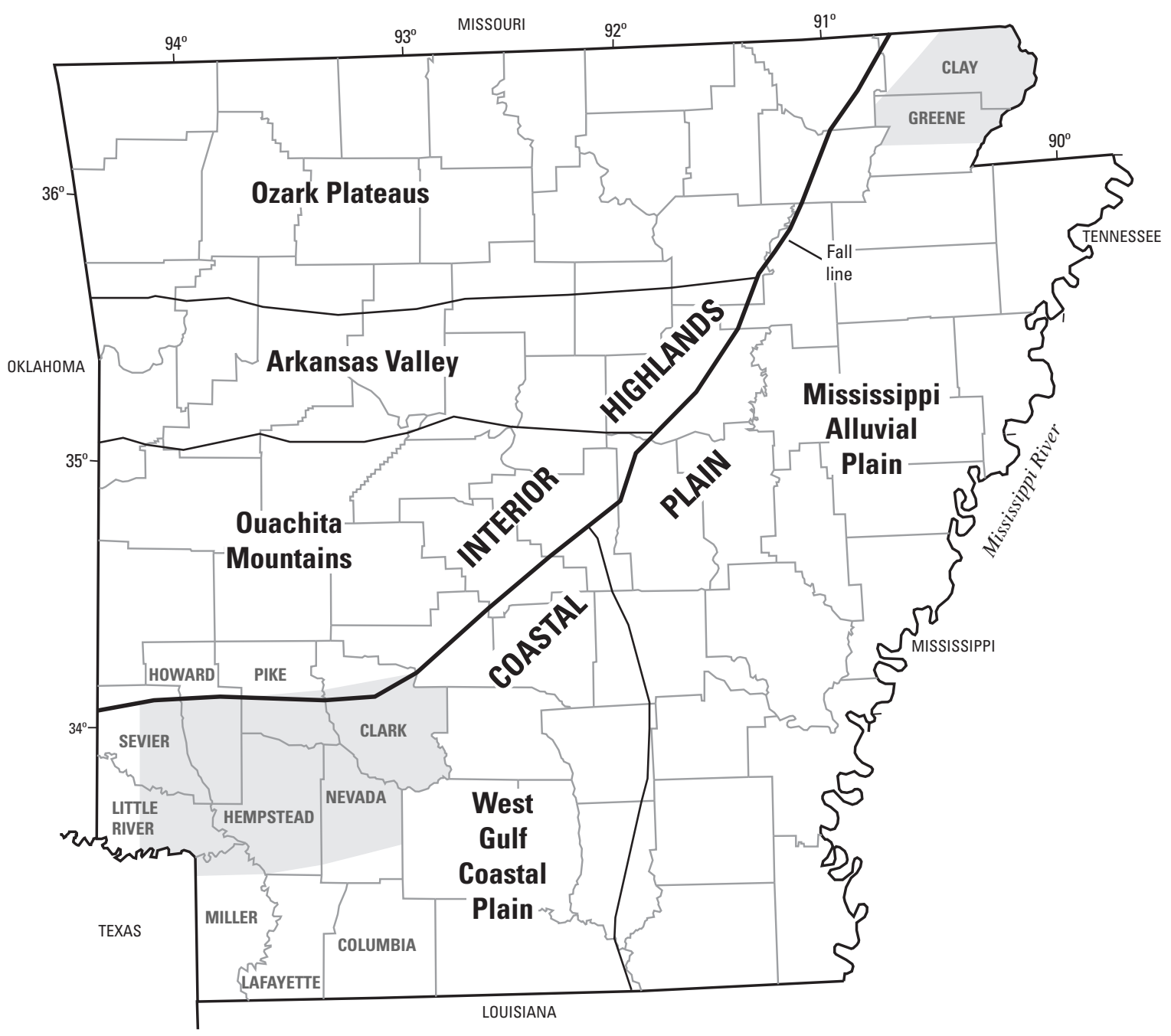

Scientific Investigations Report 2007-5024 



\section{Status of Water Levels in Aquifers in the Nacatoch Sand of Southwestern and Northeastern Arkansas and the Tokio Formation of Southwestern Arkansas, February 2005}

By T.P. Schrader

Prepared in cooperation with the

Arkansas Natural Resources Commission and the Arkansas Geological Commission

Scientific Investigations Report 2007-5024 


\section{U.S. Department of the Interior DIRK KEMPTHORNE, Secretary}

\section{U.S. Geological Survey \\ Mark D. Myers, Director}

\section{U.S. Geological Survey, Reston, Virginia: 2007}

For product and ordering information:

World Wide Web: http://www.usgs.gov/pubprod

Telephone: 1-888-ASK-USGS

For more information on the USGS--the Federal source for science about the Earth, its natural and living resources, natural hazards, and the environment:

World Wide Web: http://www.usgs.gov

Telephone: 1-888-ASK-USGS

Any use of trade, product, or firm names is for descriptive purposes only and does not imply endorsement by the U.S. Government.

Although this report is in the public domain, permission must be secured from the individual copyright owners to reproduce any copyrighted materials contained within this report.

Suggested citation:

Schrader, T.P., 2007, Status of water levels in aquifers in the Nacatoch Sand of southwestern and northeastern Arkansas and the Tokio Formation of southwestern Arkansas, February 2005: U.S. Geological Survey Scientific Investigations Report 2007-5024, 22 p. 


\section{Contents}

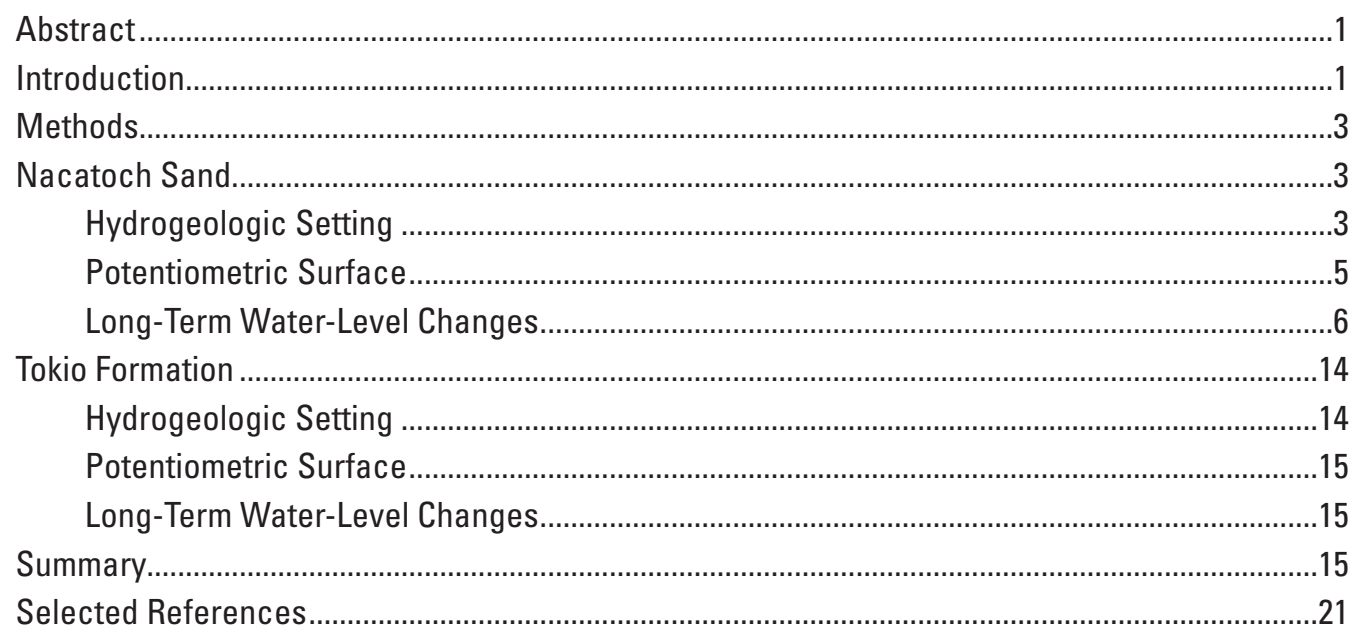

\section{Figures}

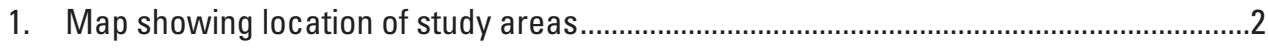

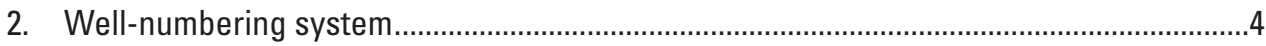

3-4. Graphs showing-

3. Estimated withdrawals by county from the Nacatoch aquifer for the northeastern study area.

4. Estimated withdrawals by county from the Nacatoch aquifer for the southwestern study area .............................................................................................

5-6. Map showing-

5. Potentiometric surface of the Nacatoch aquifer, northeastern Arkansas, February 2005

6. Potentiometric surface of the Nacatoch aquifer, southwestern Arkansas, February 2005.

7-8. Graphs showing-

7. Water level for selected wells completed in the Nacatoch aquifer..........................11

8. Estimated withdrawals by county from the Tokio aquifer for the southwestern study area

9. Map showing potentiometric surface of the Tokio aquifer, southwestern Arkansas, February 2005

10. Graphs showing water level for selected wells completed in the Tokia aquifer.............19

\section{Tables}

1. Water-level data collected during February 2005 from wells completed in the Nacatoch aquifer

2. Water-level data collected during February 2005 from wells completed in the Tokio aquifer. 


\section{Conversion Factors, Abbreviations, and Datums}

\begin{tabular}{lll}
\hline \multicolumn{1}{c}{ Multiply } & By & \multicolumn{1}{c}{ To obtain } \\
\hline foot $(\mathrm{ft})$ & Length & \\
mile $(\mathrm{mi})$ & 0.3048 & meter $(\mathrm{m})$ \\
\hline & 1.609 & kilometer $(\mathrm{km})$ \\
\hline foot per year $(\mathrm{ft} / \mathrm{yr})$ & Flow rate & \\
cubic foot per second $(\mathrm{ft} 3 / \mathrm{s})$ & 0.3048 & meter per year $(\mathrm{m} / \mathrm{yr})$ \\
gallon per minute $(\mathrm{gal} / \mathrm{min})$ & 0.02832 & cubic meter per second $\left(\mathrm{m}^{3} / \mathrm{s}\right)$ \\
gallon per day $(\mathrm{gal} / \mathrm{d})$ & 0.06309 & liter per second $(\mathrm{L} / \mathrm{s})$ \\
million gallons per day $(\mathrm{Mgal} / \mathrm{d})$ & 0.003785 & cubic meter per day $\left(\mathrm{m}^{3} / \mathrm{d}\right)$ \\
& 0.04381 & cubic meter per second $\left(\mathrm{m}^{3} / \mathrm{s}\right)$ \\
\hline
\end{tabular}

Vertical coordinate information is referenced to the National Geodetic Vertical Datum of 1929 (NGVD 1929).

Horizontal coordinate information is referenced to the North American Datum of 1983 (NAD 1983). 


\title{
Status of Water Levels in Aquifers in the Nacatoch Sand of Southwestern and Northeastern Arkansas and the Tokio Formation of Southwestern Arkansas, February 2005
}

\author{
By T.P. Schrader
}

\section{Abstract}

The Nacatoch Sand and Tokio Formation aquifers in southwestern Arkansas and the Nacatoch Sand aquifer in northeastern Arkansas are sources of water for industrial, public supply, domestic, and agricultural uses. Potentiometric-surface maps were constructed from water-level measurements made in 60 wells completed in the Nacatoch Sand and 50 wells completed in the Tokio Formation during February 2005. Aquifers in the Nacatoch Sand and Tokio Formation are hereafter referred to as the Nacatoch aquifer and Tokio aquifer, respectively.

The direction of ground-water flow in the Nacatoch aquifer in northeastern Arkansas generally is towards the southeast. The potentiometric high is located along the north and northwestern boundaries of the area.

The direction of ground-water flow in the Nacatoch aquifer in southwestern Arkansas is towards the south-southeast in Little River, Miller, and Hempstead Counties and to the eastsoutheast in Nevada and Clark Counties. The potentiometric high is located within the outcrop area in north-central Hempstead County. A cone of depression exists in the Nacatoch aquifer at Hope in southeastern Hempstead County.

The direction of ground-water flow in the Tokio aquifer in southwestern Arkansas generally is towards the south or southeast. The potentiometric high is within the outcrop area. An area of artesian flow exists in southeastern Pike, northeastern Hempstead, and northwestern Nevada Counties. One apparent cone of depression might exist northwest of Hope in Hempstead County.

In northeastern Arkansas, withdrawals from the Nacatoch aquifer increased by 516 percent from 1965 to 2000. In southwestern Arkansas, withdrawals from Nacatoch aquifer and Tokio aquifer increased by 125 percent and 201 percent, respectively, from 1965 to 1980 and decreased by 93 percent and 80 percent, respectively, from 1980 to 2000. Long-term hydrographs were prepared for 10 wells in the study areas. Changes in water levels in some wells may be associated with changes in withdrawals from the respective aquifers.

\section{Introduction}

Ground water is a renewable resource important for economic growth and quality of life. Aquifers in the Nacatoch Sand and Tokio Formation in southwestern Arkansas and the Nacatoch Sand in northeastern Arkansas are sources of water for industrial, public supply, domestic, and agricultural uses. Monitoring of ground-water levels and withdrawals provides information needed to effectively plan and manage the resource. A study was conducted in cooperation with the Arkansas Natural Resources Commission and the Arkansas Geological Commission to provide potentiometric-surface maps and water-level hydrographs associated with aquifers in the Nacatoch Sand and Tokio Formation (hereafter referred to as the Nacatoch aquifer and Tokio aquifer, respectively) in southwestern Arkansas and the Nacatoch aquifer in northeastern Arkansas.

The study areas comprise parts of 10 counties in two areas of northeastern and southwestern Arkansas. The northeastern study area includes most of Clay and Greene Counties in the Mississippi Alluvial Plain physiographic province (fig. 1). This area is bounded on the north and east by the Missouri State line and on the west by the western extent of the Nacatoch aquifer. The southern boundary of this area was defined by the southern extent of water withdrawals from wells screened in the Nacatoch aquifer. The southwestern study area includes parts of eight counties (Clark, Hempstead, Howard, Little River, Miller, Nevada, Pike, and Sevier) in the West Gulf Coastal Plain physiographic province (fig. 1). This area is bounded on the north approximately by the Fall Line separating the Interior Highlands from the West Gulf Coastal Plain, on the west by the extent of use and the availability of wells, and on the east by the eastern borders of Clark and Nevada Counties. The southwestern study area was limited to the occurrence of freshwater; the southern boundary of the area is defined by a freshwater/saltwater interface. To the south, the ground water is considered saline (more than 1,000 milligrams per liter of dissolved solids) and is not suitable for most uses (Boswell and others, 1965; Petersen and others, 1985). 


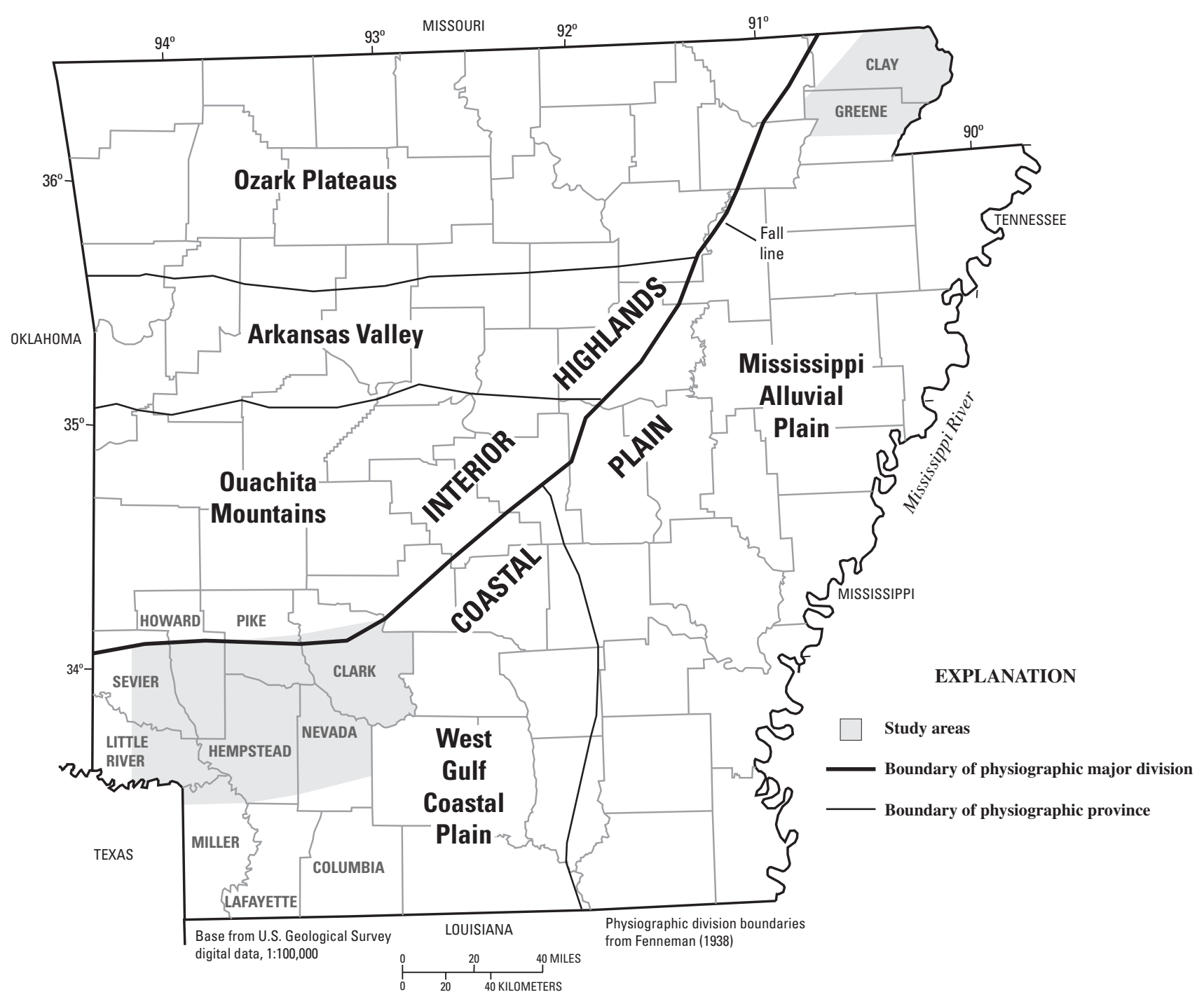

Figure 1. Location of study areas.

This report presents the results of water-level measurements made in 60 wells completed in the Nacatoch aquifer and in 50 wells completed in the Tokio aquifer during February 2005. These measurements were used to construct potentiometric-surface maps. All water-level data are stored in the U.S. Geological Survey's Ground-Water Site Inventory (GWSI) data storage system (http://waterdata.usgs.gov). Long-term water-level hydrographs were prepared for selected wells. Withdrawal data for the aquifers in each county collected by the U.S. Geological Survey from 1965 to 2000 were related to these hydrographs. The Tokio Formation is stratigraphically below the Nacatoch Sand and separated from it by five stratigraphic units, listed here in descending stratigraphic order: Saratoga Chalk, Marlbrook Marl, Annona Chalk, Ozan Forma- tion, and Brownstown Marl. The Saratoga Chalk, Marlbrook Marl, and Annona Chalk are non-water bearing and the fiveunit section can obtain a thickness of 900 feet (ft). These five units rarely are used as water sources and are not discussed in this report.

Cones of depression within a potentiometric surface are indicators of pumping rates that are exceeding the local recharge rates to the aquifer. As a well is pumped, water levels are drawn down, forming a local cone of depression. Water levels will recover over time if pumping rates do not exceed the recharge rates to the aquifer. Pumping rates that exceed recharge rates for an extended period of time will cause cones of depression to enlarge. Local cones of depression can intersect and coalesce, causing a regional decrease in water 
levels within the aquifer. Variations in climatic conditions and resulting recharge rates can result in the natural rise or decline of water levels and could account for changes shown by longterm hydrographs.

The well-numbering system used in this report is based upon the location of the wells according to the Federal land survey used in Arkansas. The component parts of a well number are the township number; the range number; the section number; three letters which indicate, respectively, the quarter section, the quarter-quarter section, and the quarter-quarterquarter section in which the well is located; and a sequence number of the well in the quarter-quarter-quarter section. The letters are assigned counterclockwise, beginning with " $\mathrm{A}$ " in the northeast quarter or quarter-quarter or quarter-quarterquarter section in which the well is located. For example, well 01S03W04BBD16 (fig. 2) is located in Township 1 South, Range 3 West, and in the southeast quarter of the northwest quarter of the northwest quarter of section 4 . This well is the 16th well in this quarter-quarter-quarter section of section 4 from which data were collected.

\section{Methods}

Personnel from the U.S. Geological Survey collected water-level measurements during February 2005 from wells screened in either the Nacatoch aquifer or Tokio aquifer. Measurements were collected using steel or electric tapes graduated in hundredths of a foot. The steel and electric tapes were calibrated during January 2005. Well locations were measured using a Global Positioning System receiver to acquire the horizontal coordinate information, latitude and longitude, based on the North American Datum of 1983. The latitude and longitude of the well location was transferred to the appropriate topographic map and the altitude (National Geodetic Vertical Datum of 1929 (NGVD of 1929)) determined.

\section{Nacatoch Sand}

\section{Hydrogeologic Setting}

The Nacatoch Sand of Upper Cretaceous age is underlain by the Saratoga Chalk and overlain by the Arkadelphia Marl. In the northeastern area, the Nacatoch Sand subcrops beneath Quaternary alluvial and terrace deposits along the western boundary. The top of the Nacatoch Sand has an altitude of about 50 to $100 \mathrm{ft}$ above NGVD of 1929 along the western boundary, dips toward the southeast, and descends to about 1,200 ft below NGVD of 1929 at the Mississippi River. The unit is about $100 \mathrm{ft}$ thick near the subcrop and attains a maximum thickness of about $600 \mathrm{ft}$ downdip (Petersen and others, 1985).
The Nacatoch Sand in the northeastern study area consists of interbedded clay, limestone, and fine sand in the lower part, grading upward to loose fine quartz sand in the upper part (Petersen and others, 1985). The Nacatoch aquifer receives recharge from precipitation through the overlying alluvium and terrace deposits in western Clay and Greene Counties.

In the southwestern study area, the Nacatoch Sand outcrops in a belt 3 to 8 miles (mi) wide extending from central Clark County southwestward to western Hempstead County. The belt continues westward as a subcrop below Quaternary alluvial and terrace deposits across Little River County (Boswell and others, 1965). The top of the Nacatoch Sand has an altitude of about $300 \mathrm{ft}$ above NGVD of 1929 in the outcrop, dips towards the southeast, and descends to about 800 $\mathrm{ft}$ below NGVD of 1929 at the southern boundary of the area. The Nacatoch Sand is about $100 \mathrm{ft}$ thick near the outcrop and attains a maximum thickness of $600 \mathrm{ft}$ (Petersen and others, 1985).

The Nacatoch Sand in the southwestern study area consists of three distinct units. The upper unit is composed of unconsolidated, gray, fine-grained quartz sand that commonly is cross bedded. Locally the sand is massive and contains a few hard lenses and beds of fossiliferous sandy limestone. This upper sand unit is the main water-bearing unit of the Nacatoch Sand. The middle unit consists of a dark-green sand that contains coarse grains of glauconite and weathers to lighter shades of green. This unit generally is fossiliferous where it is glauconitic. The lower unit consists of interbedded gray clay, sandy clay and marl, dark clay-rich fine-grained sand, and hard irregular concretionary beds (Counts and others, 1955; Plebuch and Hines, 1969).

In the southwestern study area, the Nacatoch aquifer receives recharge from precipitation in its outcrop areas in Clark, Nevada, and Hempstead Counties and through the overlying alluvium and terrace deposits in Little River County and in northeastern Texas. The Nacatoch aquifer is used in northeastern Greene County, Clay County, southern Clark County, northwestern Nevada County, central Hempstead County, northern Miller County, and southeastern Little River County. Flowing artesian wells produce yields of 1 or 2 gallons per minute (gal/min) in the lowest stream valleys in Clark and Nevada Counties. Wells in Hempstead County and western Nevada County produce yields of 150 to $300 \mathrm{gal} / \mathrm{min}$. Downdip from 2 to $20 \mathrm{mi}$ southeast of the outcrop area in the southwestern area, the water generally is excessively saline for most uses. In Miller County, eastern Nevada County, and Clark County, yields generally are small and the water may contain considerable chloride (Counts and others, 1955). Aquifer tests made using wells completed in the Nacatoch aquifer at Hope and Prescott show a transmissivity of 3,600 gallons per day per foot (gal/d/ft) (Ludwig, 1972).

Withdrawals from the Nacatoch aquifer in the northeastern study area were estimated to be 0.25 million gallons per day (Mgal/d) in 1965 and increased to $2.21 \mathrm{Mgal} / \mathrm{d}$ in 1990, an increase of 784 percent during the 25 -year period (fig. 3 ). The 


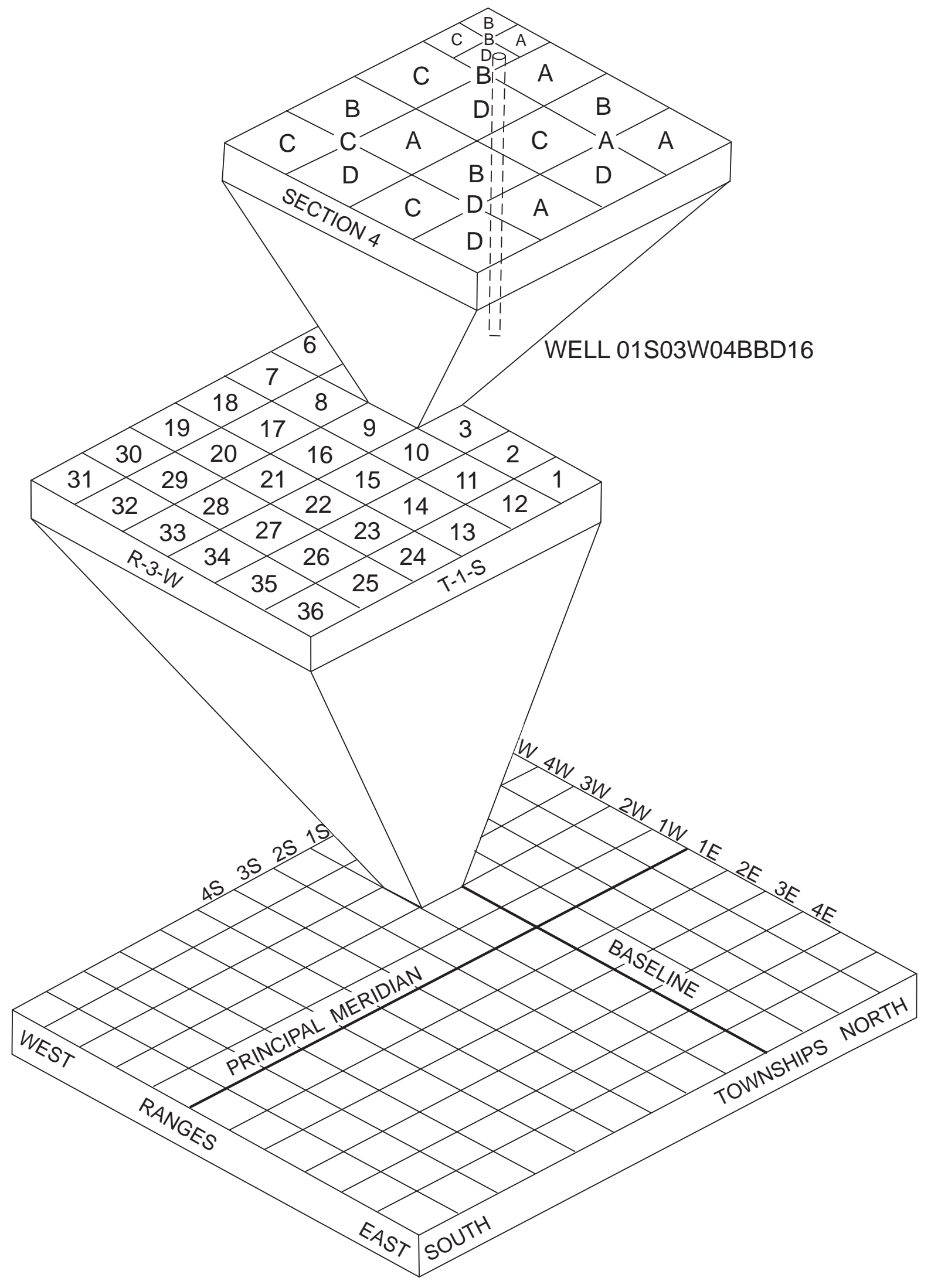

Figure 2. Well-numbering system. 


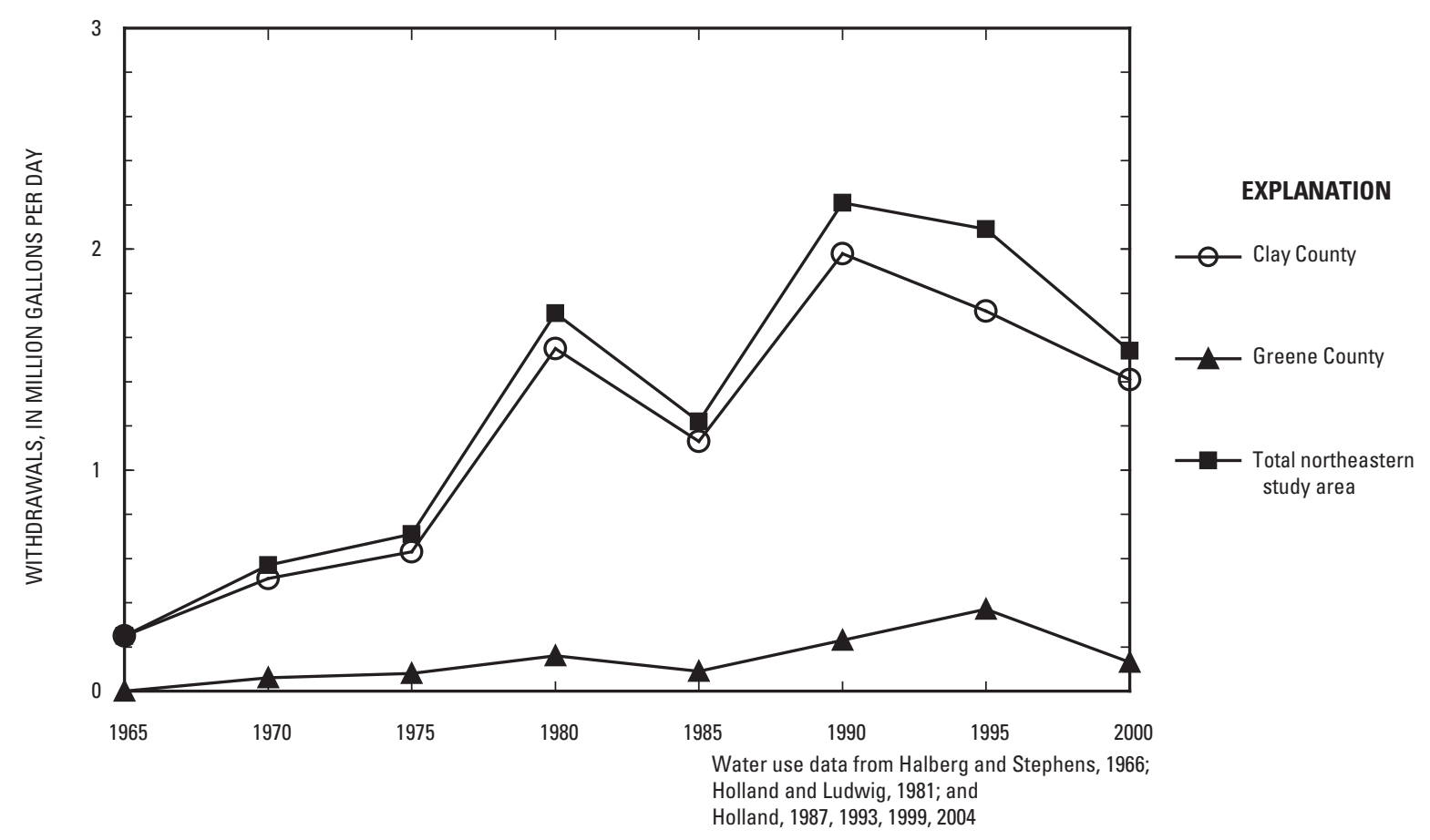

Figure 3. Estimated withdrawals by county from the Nacatoch aquifer for the northeastern study area.

amount of withdrawals in 2000 was $1.54 \mathrm{Mgal} / \mathrm{d}$, a decrease of 30 percent from 1990. From 1965 to 2000, withdrawals from the Nacatoch aquifer increased by 516 percent (Halberg and Stephens; 1966, Holland and Ludwig, 1981; Holland, 1987, 1993, 1999, 2004).

Withdrawals from the Nacatoch aquifer in the southwestern study area was estimated to be $2.11 \mathrm{Mgal} / \mathrm{d}$ in 1965 and increased by 125 percent to $4.75 \mathrm{Mgal} / \mathrm{d}$ in 1980 (fig. 4). Withdrawals from the Nacatoch aquifer in this area were estimated to be $0.32 \mathrm{Mgal} / \mathrm{d}$ in 2000 , a decrease of 93 percent from 1980. The sharp decrease in withdrawal rates is explained by public water supplies in the southwestern area converting to a surface-water source and relying less on ground-water sources (Halberg and Stephens, 1966; Holland and Ludwig, 1981; Holland, 1987, 1993, 1999, 2004).

\section{Potentiometric Surface}

Water-level measurements in 60 wells during February 2005 were used to construct potentiometric-surface maps for the Nacatoch aquifer (figs. 5 and 6; table 1). The surface is mapped by calculating the altitude of the water levels (table 1) and is represented on the figures by contour lines that connect points of equal value. The general direction of ground-water flow is perpendicular to the contour lines in the direction of downward hydraulic gradient.
In the northeastern study area, the direction of groundwater flow in the Nacatoch aquifer generally is towards the southeast (fig. 5). The potentiometric high is located along the north and northwestern boundary of this area. The highest water-level altitude measured was about $273 \mathrm{ft}$ above NGVD of 1929 (hereinafter, all water-level altitudes are referenced to NGVD of 1929) in northern Clay County. The lowest waterlevel altitude measured was about $231 \mathrm{ft}$ in eastern Greene County.

In the southwestern study area, the direction of groundwater flow in the Nacatoch aquifer is generally towards the south-southeast in Little River, Miller, and Hempstead Counties and to the east-southeast in Nevada and Clark Counties (fig. 6). The direction of flow may be affected by the increase in clay content in the downdip direction and by a fault system trending northeastward from northeastern Texas across Miller, Lafayette, and Nevada Counties in Arkansas (Boswell and others, 1965). The highest water-level altitude measured was about $443 \mathrm{ft}$ in the outcrop area of north-central Hempstead County. The lowest water-level altitude measured was about $146 \mathrm{ft}$ in Clark County.

A depression exists at Hope in Hempstead County (fig. 6). Historical water levels indicate a decline of $40 \mathrm{ft}$ from $185 \mathrm{ft}$ in 1942 to $145 \mathrm{ft}$ in 1969 (Ludwig, 1972). The waterlevel altitude from January 2002 was $119 \mathrm{ft}$ (Schrader and Scheiderer, 2004). This depression alters local ground-water 


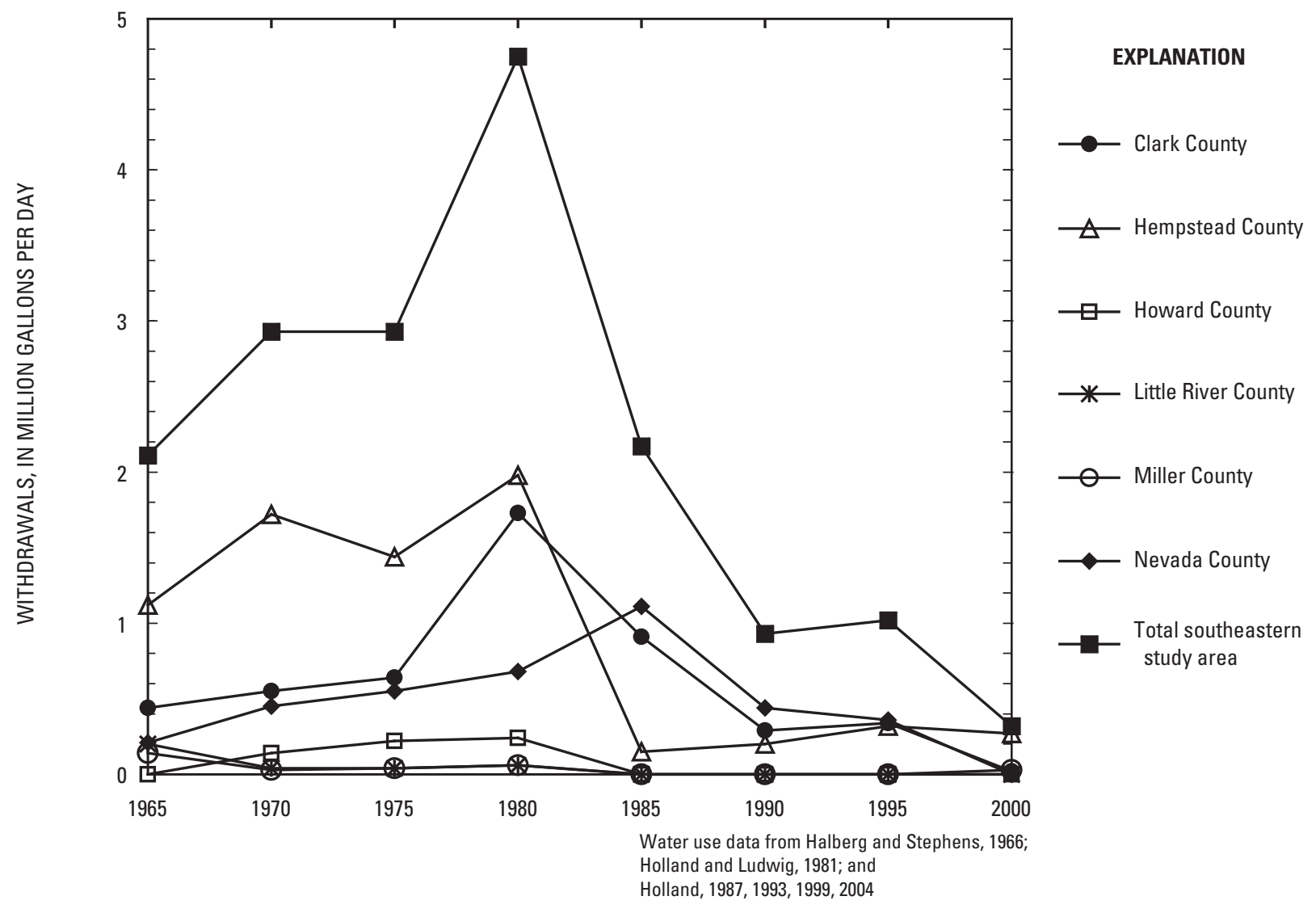

Figure 4. Estimated withdrawals by county from the Nacatoch aquifer for the southwestern study area.

flow directions from the regional direction, with ground water flowing towards Hope from the west, north, and northeast directions. A comparison with the 2002 potentiometric-surface maps (Schrader and Scheiderer, 2004) for the Nacatoch aquifer shows a substantial rise in water level at Hope from $119 \mathrm{ft}$ to $152 \mathrm{ft}$. A small depression exists in southern Clark County. The water level in the depression in southern Clark County has risen about $6 \mathrm{ft}$ from $140 \mathrm{ft}$ in 2002 to $146 \mathrm{ft}$ in 2005 . The rest of the southwest and northeast study areas have minor variations in water level when compared to the 2002 maps.

\section{Long-Term Water-Level Changes}

Six hydrographs from wells completed in the Nacatoch aquifer display long-term (minimum of 20 years) water-level altitudes (fig. 7). Linear regression was used to determine the annual decline or rise in feet per year for water levels in each well. The minimum 20-year period is used to decrease the effect of short-term variations in climate and localized pumping rates on water levels in a single well. Two wells (sites A and B, fig. 7) are located in the northeastern study area (fig. 5). Water levels in both of these wells have an annual decline of about 1.2 foot per year (ft/yr). Withdrawal rates from the Nacatoch aquifer for Greene and Clay Counties increased from $0.25 \mathrm{Mgal} / \mathrm{d}$ in 1965 to $1.54 \mathrm{Mgal} / \mathrm{d}$ in 2000, with a maximum of $2.21 \mathrm{Mgal} / \mathrm{d}$ in 1990, an increase of approximately 516 percent from 1965 to 2000 and a decrease of approximately 30 percent from 1990 to 2000 (fig. 3) (Halberg and Stephens, 1986; Holland, 1993, 2004). The decrease in water levels may be associated with the increased withdrawal from the Nacatoch aquifer in Greene and Clay Counties.

Four wells with historical water-level measurements (sites C-F; fig. 7), are located in the southwestern area (fig. 6). There is one well located in each of the following four counties: Clark, Hempstead, Miller, and Nevada Counties.

Water levels in well 08S19W09ACC1 (site C, figs. 6 and 7) declined from about $186 \mathrm{ft}$ above NGVD of 1929 in 1962 to about $178 \mathrm{ft}$ in 2005, an annual decline of about $0.2 \mathrm{ft} / \mathrm{yr}$. The consistent decline in water level does not reflect the changes in water use from the Nacatoch aquifer in Clark County (fig. 4). 


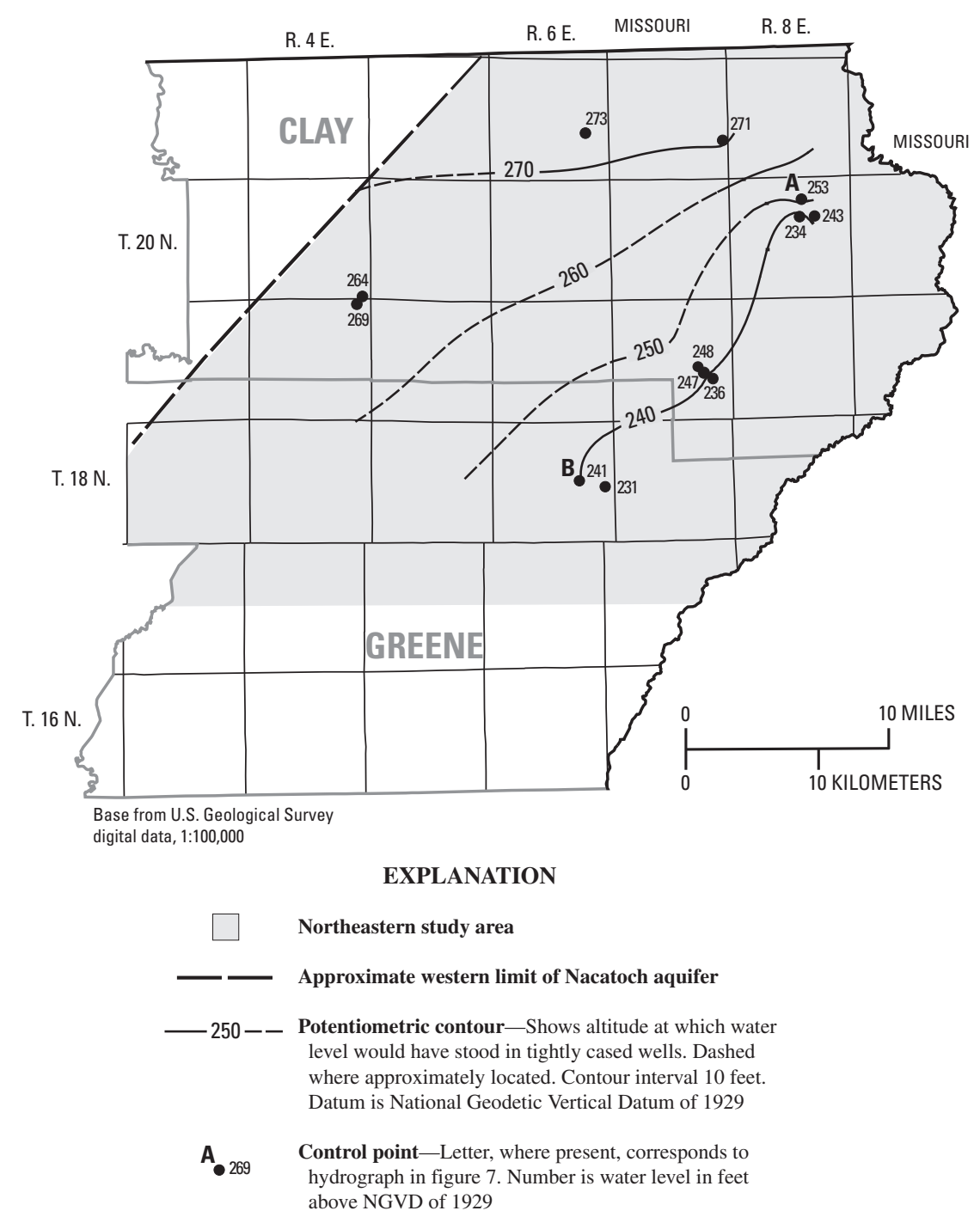

Figure 5. Potentiometric surface of the Nacatoch aquifer, northeastern Arkansas, February 2005.

Water levels in well 13S25W35DDC1 (site D, figs. 6 and 7), declined from $188 \mathrm{ft}$ in 1975 to $175 \mathrm{ft}$ in 1979. Estimated water use from the Nacatoch aquifer in Hempstead County increased from $1.44 \mathrm{Mgal} / \mathrm{d}$ in 1975 to $1.98 \mathrm{Mgal} / \mathrm{d}$ in 1980 (Halberg, 1977; Holland and Ludwig, 1981), an increase of about 38 percent (fig. 4). Water use declined from $1.98 \mathrm{Mgal} / \mathrm{d}$ in 1980 to $0.15 \mathrm{Mgal} / \mathrm{d}$ in 1985 . From 1979 to 1999 , a general rise in water level was observed, but from 1999 to 2002, a sharp decrease in water level occurred. From 2002 to 2005 a small decrease in water level occurred. Estimated wateruse rates from the Nacatoch aquifer in Hempstead County increased from $0.15 \mathrm{Mgal} / \mathrm{d}$ in 1985 to $0.32 \mathrm{Mgal} / \mathrm{d}$ in 1995 to $0.76 \mathrm{Mgal} / \mathrm{d}$ in 2000 (Holland, 1987, 1999, 2004).
Water levels in well 14S28W13CCB1 (site E, figs. 6 and 7) ranged from $248 \mathrm{ft}$ to $237 \mathrm{ft}$ from 1962 to 2005 . Waterlevel changes in this well cannot be attributed to a specific effect.

Water levels in well 11S22W08DAC2 (site F, figs. 6 and 7), rose from about $179 \mathrm{ft}$ in 1985 to about $267 \mathrm{ft}$ in 1990, an average rise of about $17.6 \mathrm{ft} / \mathrm{yr}$. The increase in water levels occurred when the estimated withdrawal rates from the Nacatoch aquifer in Nevada County decreased from 1.11 $\mathrm{Mgal} / \mathrm{d}$ in 1985 to $0.44 \mathrm{Mgal} / \mathrm{d}$ in 1990 (Holland, 1985, 2004); a decrease of about 60 percent (fig. 4). Although water levels in these six wells may be associated with changes in water use, other factors also may affect water levels such as climatic 


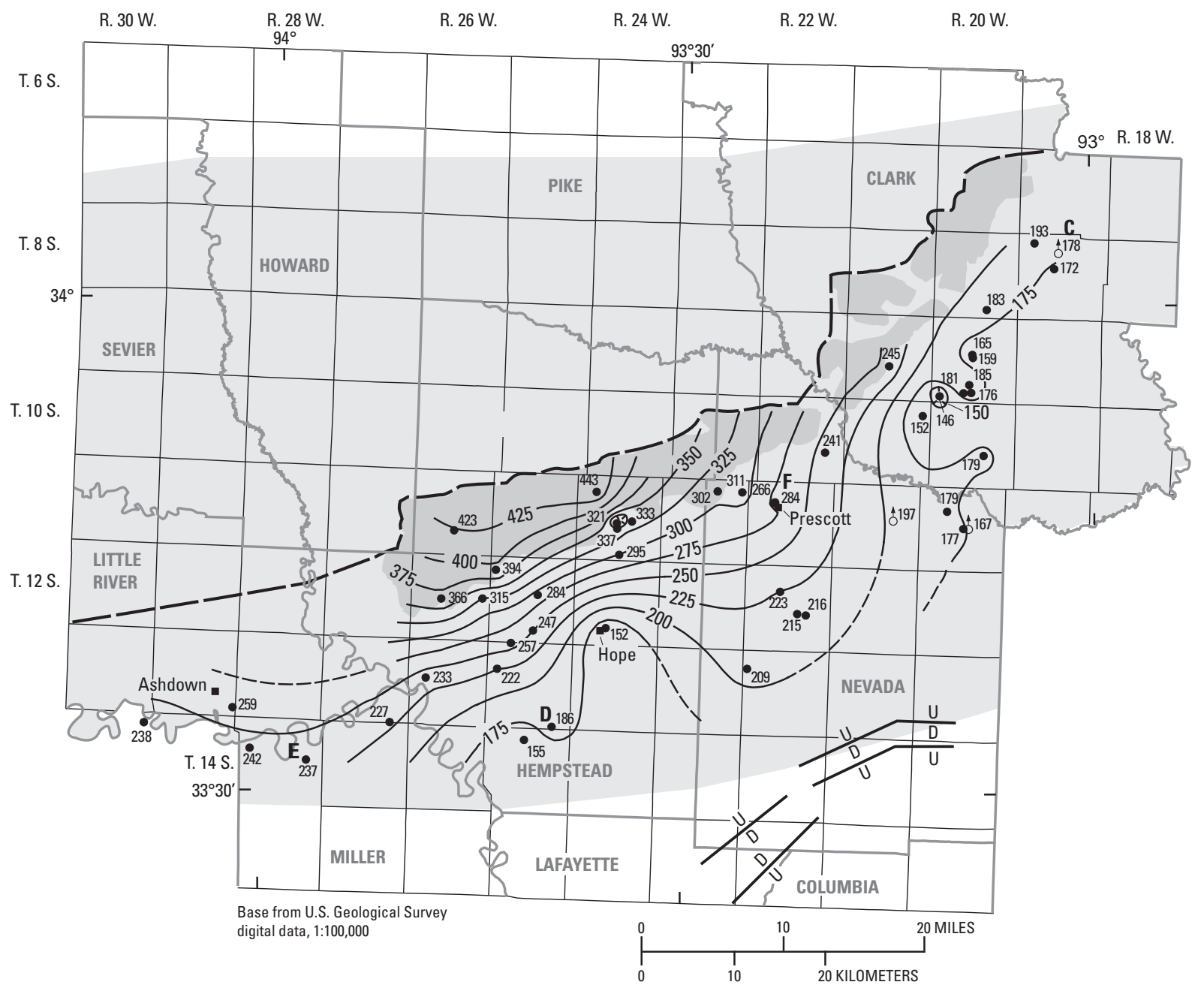

EXPLANATION

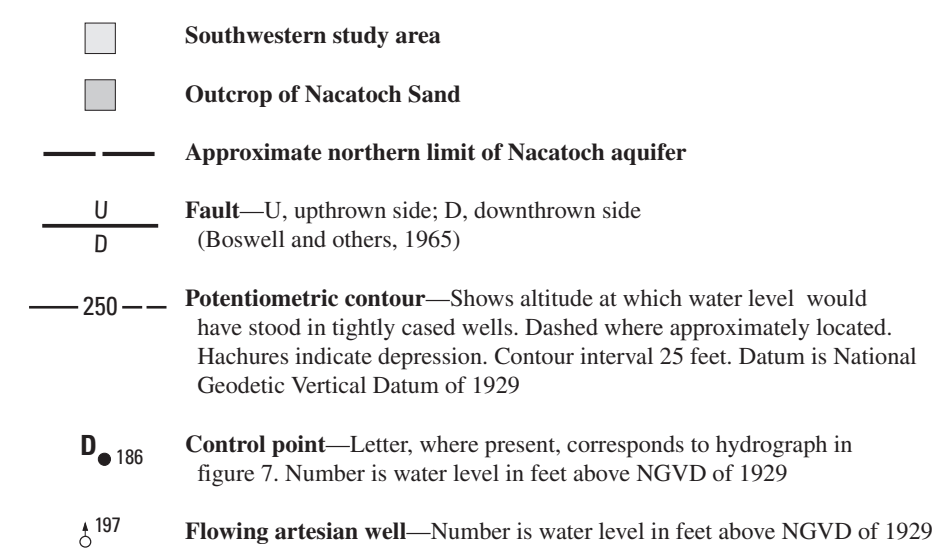

Figure 6. Potentiometric surface of the Nacatoch aquifer, southwestern Arkansas, February 2005. 
Table 1. Water-level data collected during February 2005 from wells completed in the Nacatoch aquifer.

[NGVD of 1929, National Geodetic Vertical Datum of 1929-A geodetic datum derived from a general adjustment of the first-order level nets of the United States and Canada, formerly called Sea Level Datum of 1929; Horizontal Datum is North American Datum of 1983; a negative depth to water indicates a flowing artesian well]

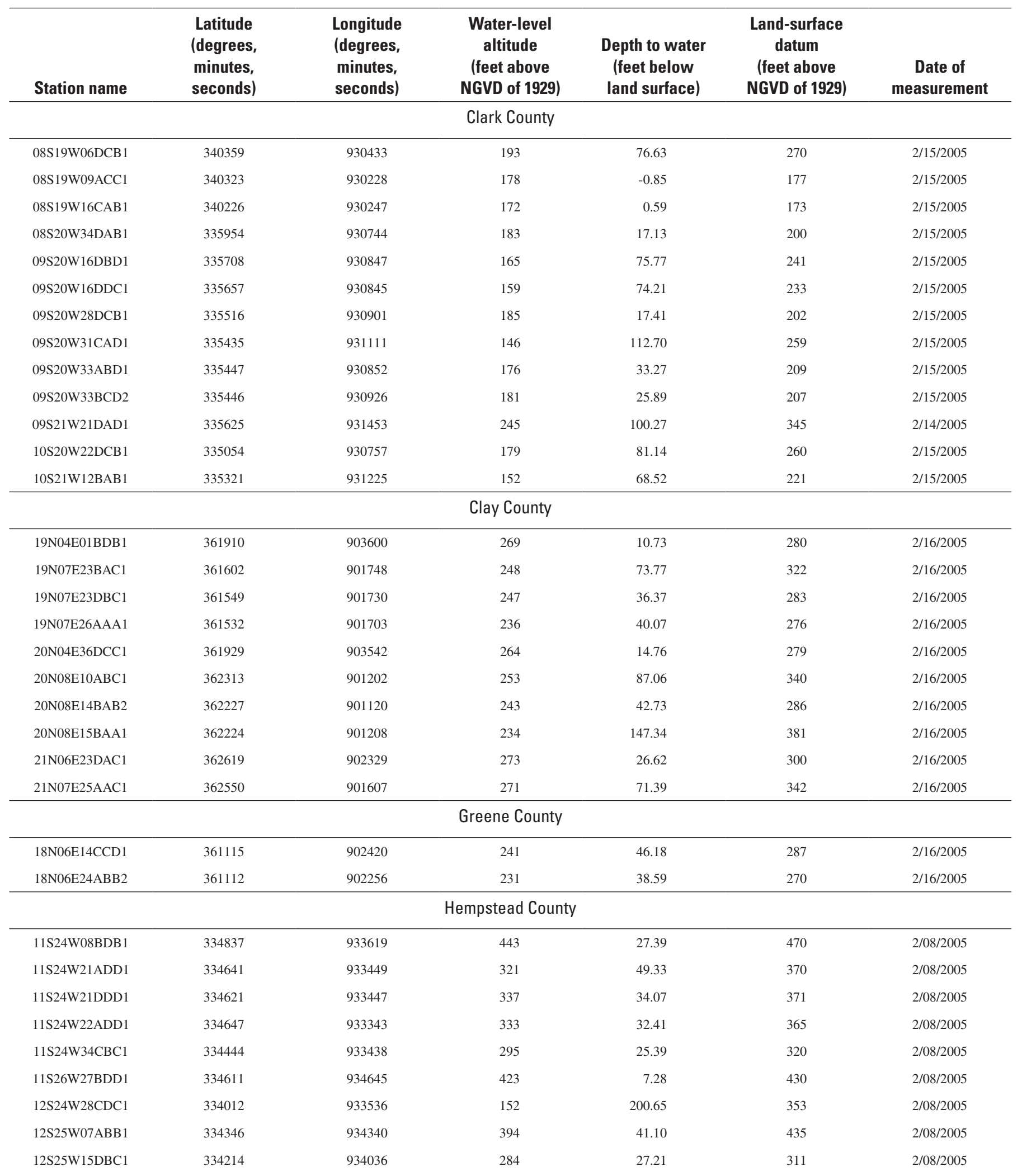


Table 1. Water-level data collected during February 2005 from wells completed in the Nacatoch aquifer. —Continued

[NGVD of 1929, National Geodetic Vertical Datum of 1929-A geodetic datum derived from a general adjustment of the first-order level nets of the United States and Canada, formerly called Sea Level Datum of 1929; Horizontal Datum is North American Datum of 1983; a negative depth to water indicates a flowing artesian well]

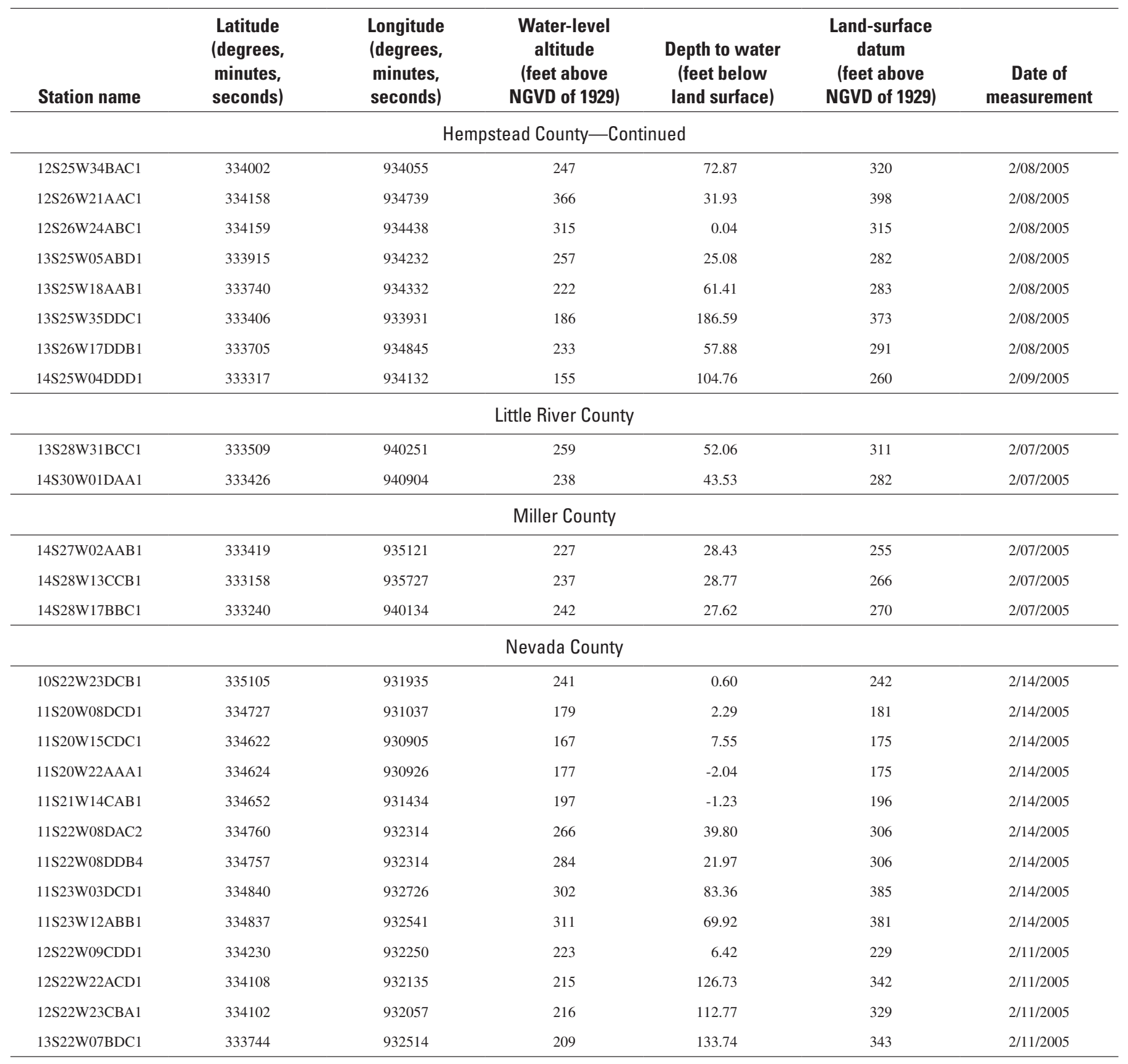




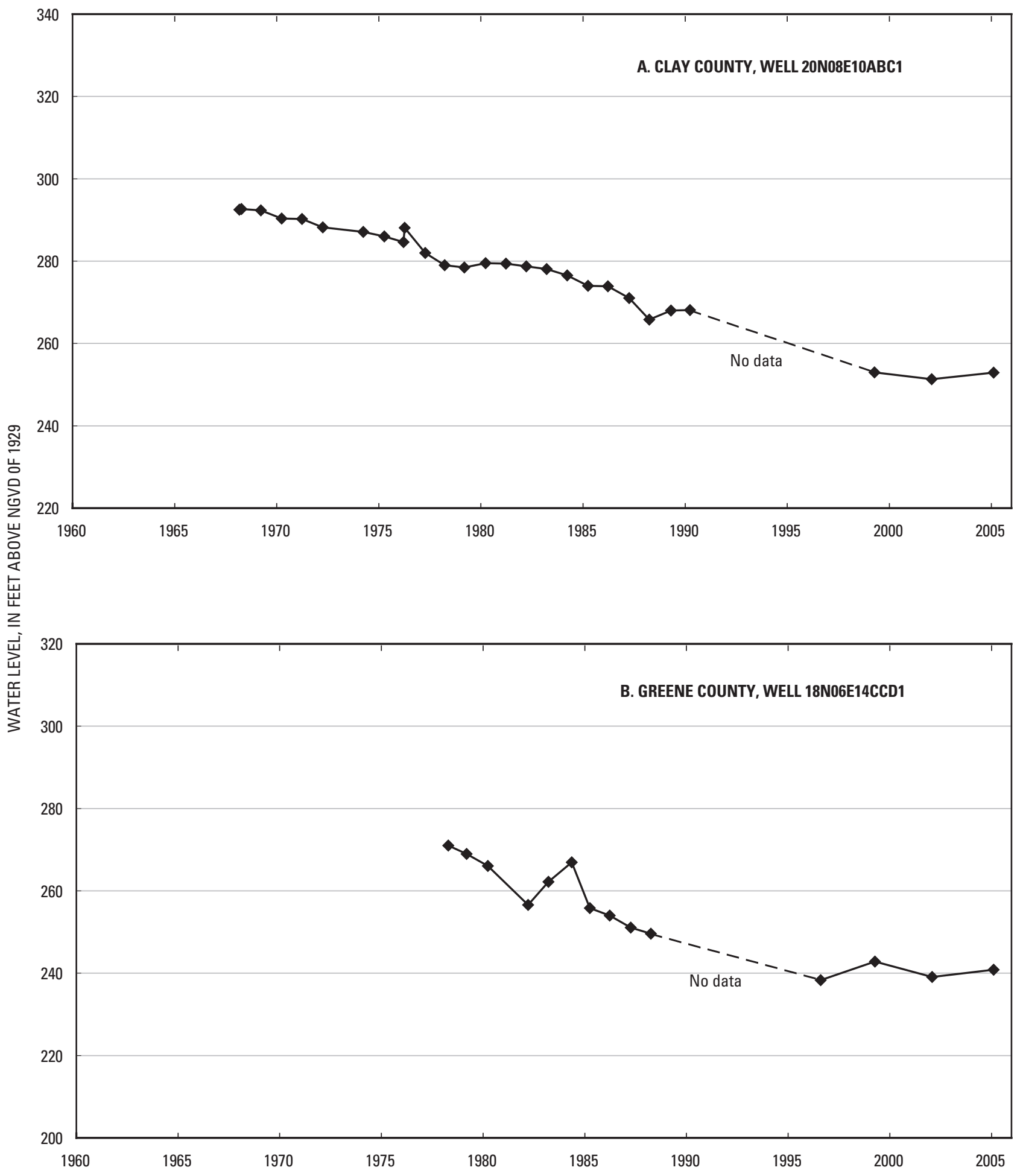

Figure 7. Water level for selected wells completed in the Nacatoch aquifer. 


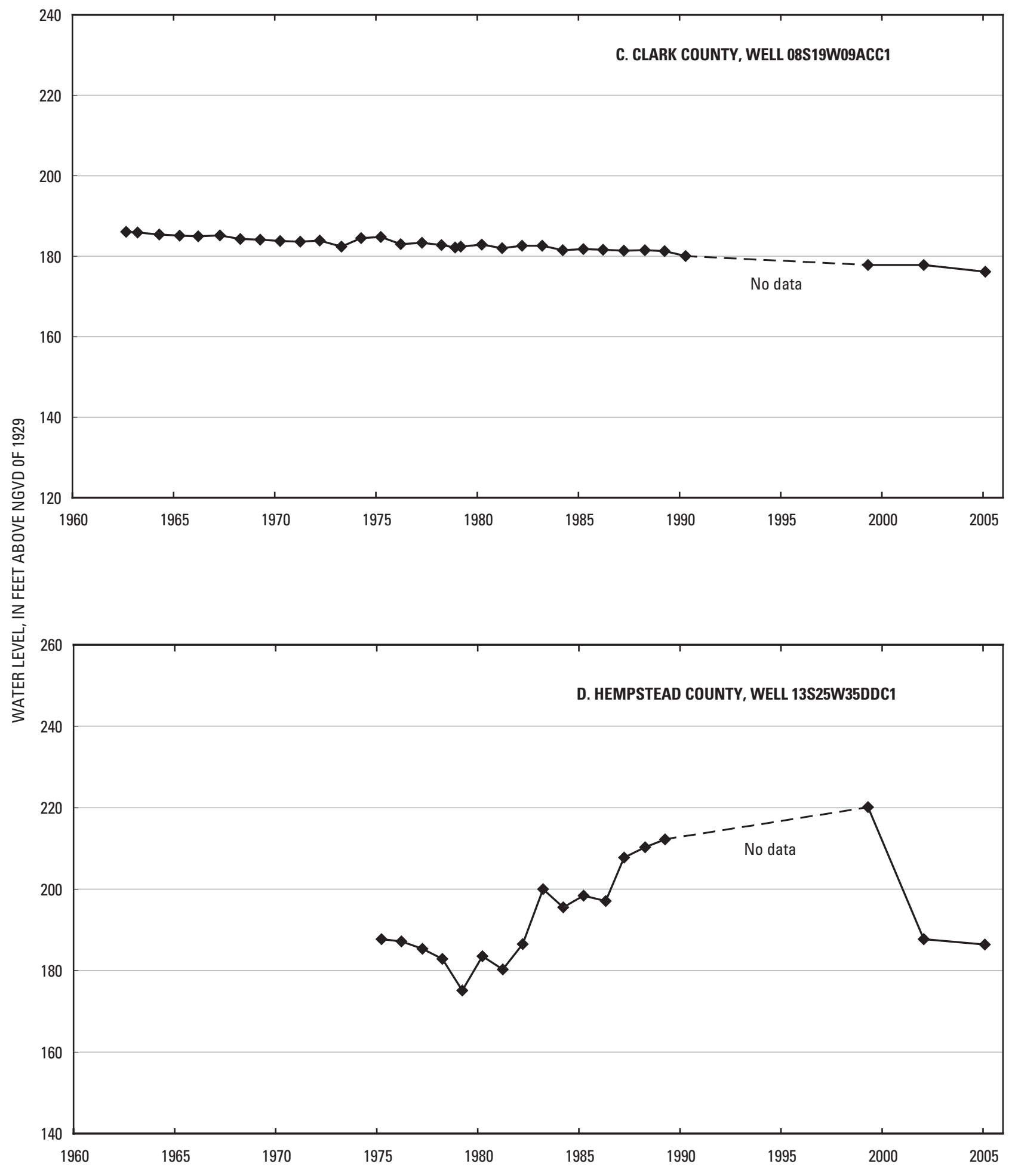

Figure 7. Water level for selected wells completed in the Nacatoch aquifer.-Continued 


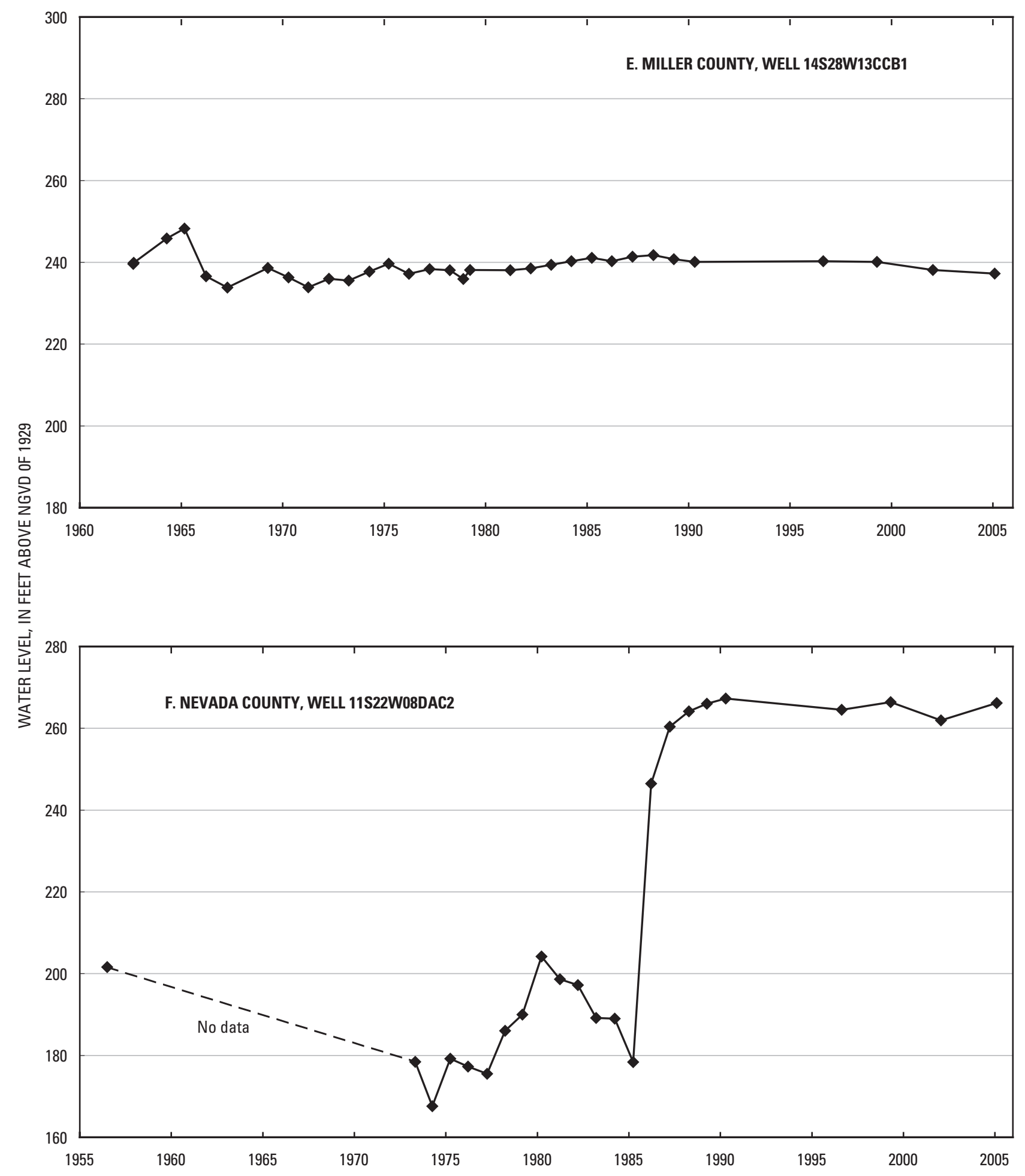

Figure 7. Water level for selected wells completed in the Nacatoch aquifer-—Continued 
variations or changes in leakage to and from overlying and underlying rock units.

\section{Tokio Formation}

\section{Hydrogeologic Setting}

The Tokio Formation of Cretaceous age underlies the Brownstown Marl and overlies consolidated rocks of Mississippian and Pennsylvanian age in Clark and northeastern Nevada Counties (Plebuch and Hines, 1969); the Trinity Group of Early Cretaceous age in Pike, Nevada, Miller, and most of Hempstead Counties (Petersen and others, 1985); and the Woodbine Formation of Late Cretaceous age in Little River, Sevier, Howard, and northwestern Hempstead Counties (Boswell and others, 1965). The Tokio Formation outcrops in a southwest-to-northeast trending band from east Sevier County to west-central Clark County. The outcrop attains a maximum width of about $10 \mathrm{mi}$ in Howard County and extends southwest into Sevier County approximately 8 mi. In this area, the Tokio Formation is overlain in several places by terrace deposits of Quaternary alluvium. The unit also outcrops in northwestern Little River County, west of the study area. The unit ranges in thickness from about $50 \mathrm{ft}$ to more than $300 \mathrm{ft}$, dips towards the southeast, and is composed of discontinuous, interbedded gray clay and poorly sorted, cross-bedded quartz sands, lignite, and a prevalent basal gravel (Counts and others, 1955; Boswell and others, 1965; Plebuch and Hines, 1969; Petersen and others; 1985). The Tokio Formation does not occur in the northeastern area.

The Tokio aquifer receives recharge from precipitation where it outcrops or is overlain by permeable alluvial and terrace deposits. Salinity increases downdip to the southsoutheast. The Tokio aquifer yields freshwater to within a few miles north of Ashdown in Little River County then becomes slightly to moderately saline downdip (southeast) from near Prescott to the fault zone trending across Nevada County (Petersen and others, 1985).

The Tokio aquifer yields potable water to wells in eastern Little River County, southeastern Sevier County, southern Howard and Pike Counties, western Clark County, northern and central Hempstead County, and northwestern Nevada County. Wells penetrating the Tokio aquifer range in depth from a few feet in the outcrop area to about 1,200 ft at Hope and Prescott (Ludwig, 1972). Wells in central Hempstead County yield up to $300 \mathrm{gal} / \mathrm{min}$. Wells flowing as much as 90 $\mathrm{gal} / \mathrm{min}$ occur in the bottom-land areas adjacent to streams (Counts and others, 1955). Historic records indicate that water levels in the aquifer did not decline appreciably from 1950 to 1968, and that water levels had not been greatly affected by withdrawal of water at Hope and Prescott during this period (Ludwig, 1972). Estimates of water withdrawn from the Tokio aquifer increased by 201 percent from $2.0 \mathrm{Mgal} / \mathrm{d}$ in 1965 to $6.02 \mathrm{Mgal} / \mathrm{d}$ in 1980 (fig. 8). Water withdrawn from the Tokio

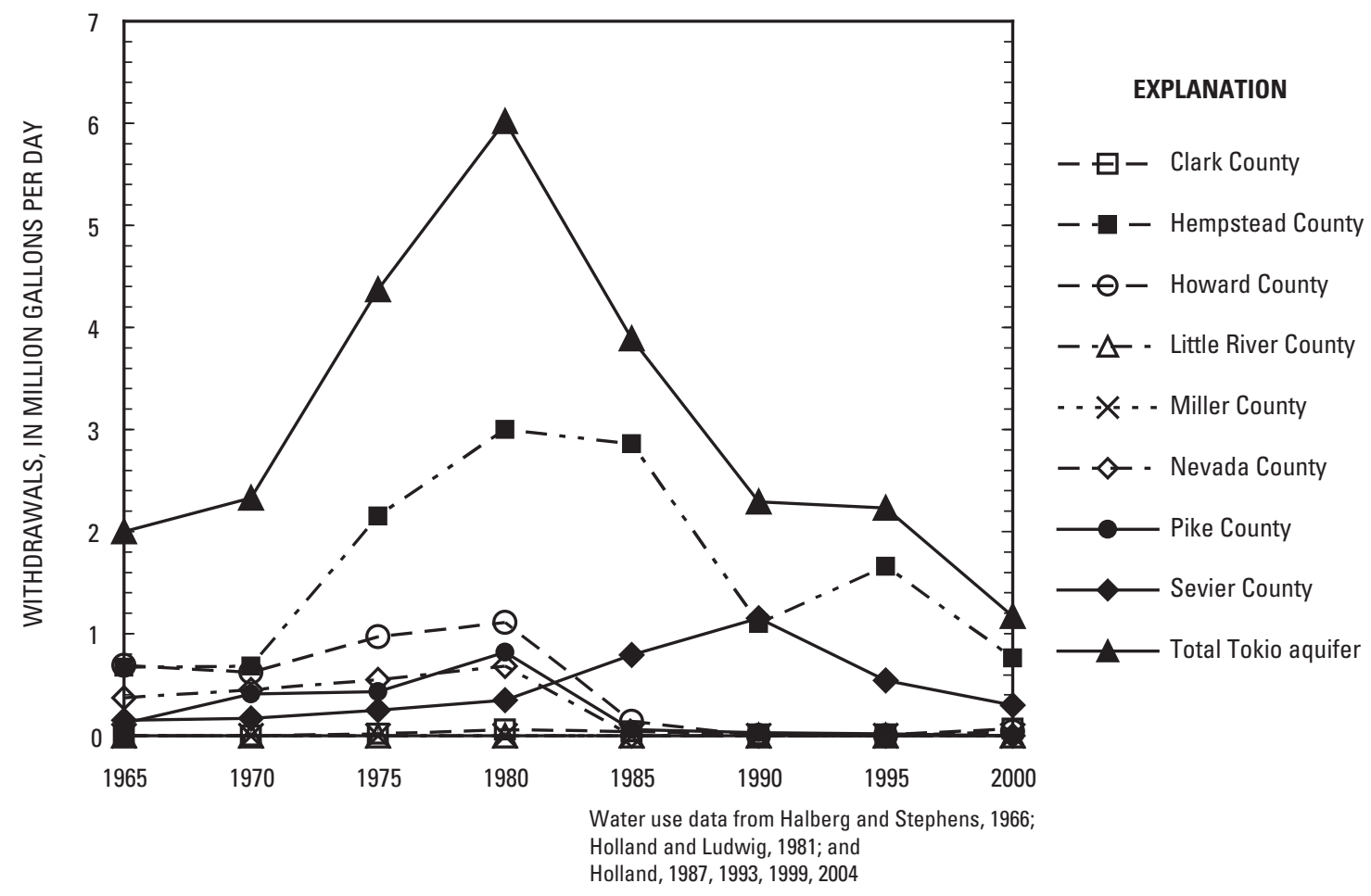

Figure 8. Estimated withdrawals by county from the Tokio aquifer for the southwestern study area. 
aquifer was estimated to be $1.17 \mathrm{Mgal} / \mathrm{d}$ in 2000, a decrease of 80 percent from 1980 (Halberg and Stephens, 1966; Holland and Ludwig, 1981; Holland, 1999, 2004).

\section{Potentiometric Surface}

The potentiometric surface for the Tokio aquifer shows the altitude that water would have stood in tightly cased wells screened in the aquifer (fig. 9). Water-level measurements in 50 wells during February 2005 were used to construct the map (table 2). The surface is mapped by determining the altitude of the water levels and is represented on the map by contour lines that connect points of equal value. The general direction of ground-water flow is perpendicular to the contours in the direction of downward hydraulic gradient.

In the southwestern study area, the direction of groundwater flow in the Tokio aquifer generally is towards the south or southeast. The potentiometric high is within the outcrop area in the northwestern part of the southwestern study area. The highest water-level altitude measured was about $490 \mathrm{ft}$ above NGVD of 1929 in Howard County. The lowest waterlevel altitude measured was about $131 \mathrm{ft}$ above NGVD of 1929 about 5 mi northwest of Hope in Hempstead County. An area of artesian flow exists in southeastern Pike, northeastern Hempstead, and northwestern Nevada Counties as evidenced by eight flowing artesian wells.

A cone of depression may exist about 5 mi northwest of Hope. The northern half of an apparent cone of depression northwest of Hope is shown on figure 9. Water-level data in the Tokio aquifer were not available south of this area. No other cones of depression were evident in the Tokio aquifer. A comparison of the 2005 map with the 2002 and 1999 potentiometric surface maps for the Tokio aquifer shows one substantial change; the 300-foot contour is positioned further north in Howard County. The change in this contour is the result of the addition of the measurement at well 10S27W02ACD1, which had not been collected in 2002 .

\section{Long-Term Water-Level Changes}

Four hydrographs from wells completed in the Tokio aquifer have long-term (minimum of 20 years) water-level altitudes (fig. 10). Two wells are located in Hempstead County (sites $\mathrm{G}$ and $\mathrm{H}$ ) and the other two wells are located in Howard (site I) and Nevada (site J) Counties (fig. 9). Linear regression was used to determine the annual decline or rise in feet per year for water levels in each well. The minimum 20-year period is used to decrease the effect of short-term variations in climate and localized pumping rates on water levels in a single well. The range of values for the annual decline or rise in water level for wells in the Tokio aquifer was -2.78 to 1.28 $\mathrm{ft} / \mathrm{yr}$, with a mean value of $-0.35 \mathrm{ft} / \mathrm{yr}$.

The two hydrographs in Hempstead County show differences between water-level trends over long periods. In well 09S23W33CDA1 (site G, figs. 9 and 10), water levels generally declined at about $0.29 \mathrm{ft} / \mathrm{yr}$ from 1958 to 2005 . Water levels in well 12S24W06DAD1 (site H, figs. 9 and 10) fluctuated through a range of about 276 to about $133 \mathrm{ft}$ over a 35 -year period. Water levels generally declined from 1971 to 1979 , generally rose from 1979 to 1989, then declined from 1989 to 1999 . The annual decline in water level at well 12S24W06DAD1 from 1971 to 2005 was $2.78 \mathrm{ft} / \mathrm{yr}$. Estimated withdrawals from the Tokio aquifer in Hempstead County (fig.

8) increased from about $0.7 \mathrm{Mgal} / \mathrm{d}$ in 1970 to about $3.0 \mathrm{Mgal} / \mathrm{d}$ in 1980, an increase of about 329 percent. Withdrawal rates decreased to about 1.1 Mgal/d from 1980 to 1990, a decrease of about 63 percent from 1980. Withdrawal rates rose to 1.7 $\mathrm{Mgal} / \mathrm{d}$ in 1995, then declined to about $0.8 \mathrm{Mgal} / \mathrm{d}$ in 2000. The decline and rise in water levels in well 12S24W06DAD1 may be associated with the fluctuating withdrawals from the Tokio aquifer in Hempstead County, while water levels in well 09S23W33CDA1 do not appear to have a similar association.

In Howard County, water levels in well 09S28W20DAC1 (site I, figs. 9 and 10) range from about $476 \mathrm{ft}$ to about 464 ft over a 48-year period from 1957 to 2005. No substantial rises or declines in water levels were observed. There does not appear to be any association between water levels in this well and estimated withdrawals from the Tokio aquifer for Howard County (fig. 8).

In Nevada County, water levels in well 11S22W08DAC1 (site J, figs. 9 and 10) declined from about $211 \mathrm{ft}$ in 1972 to about $150 \mathrm{ft}$ in 1985, with a minimum of $135 \mathrm{ft}$ in 1981. This is an annual decline of about $4.7 \mathrm{ft} / \mathrm{yr}$. Estimated withdrawal rates from the Tokio aquifer for Nevada County increased from $0.45 \mathrm{Mgal} / \mathrm{d}$ in 1970 to $0.68 \mathrm{Mgal} / \mathrm{d}$ in 1980 , an increase of 51 percent (fig. 8). From 1985 to 1987, a rise in water level to about $225 \mathrm{ft}$ was observed, which is approximately a 37.5 $\mathrm{ft} / \mathrm{yr}$ rise. Water-withdrawal rates from the Tokio aquifer for Nevada County are estimated to have decreased to zero by 1985. The decline and rise in water levels may be associated with the increased and decreased withdrawals from the Tokio aquifer in Nevada County.

Although water levels in these four wells may be associated with changes in water use, other factors also may affect water levels such as climatic variations or changes in leakage to and from overlying and underlying rock units.

\section{Summary}

Aquifers in the Nacatoch Sand and Tokio Formation in southwestern Arkansas and the Nacatoch Sand in northeastern Arkansas are sources of water for industrial, public supply, domestic, and agricultural uses. Potentiometric-surface maps were constructed from water-level measurements made in 60 wells completed in the Nacatoch Sand and 50 wells completed in the Tokio Formation during February 2005. In northeastern Arkansas, withdrawals from the Nacatoch aquifer increased by 516 percent from 1965 to 2000. In southwestern Arkansas, withdrawals from the Nacatoch and Tokio aquifers increased 


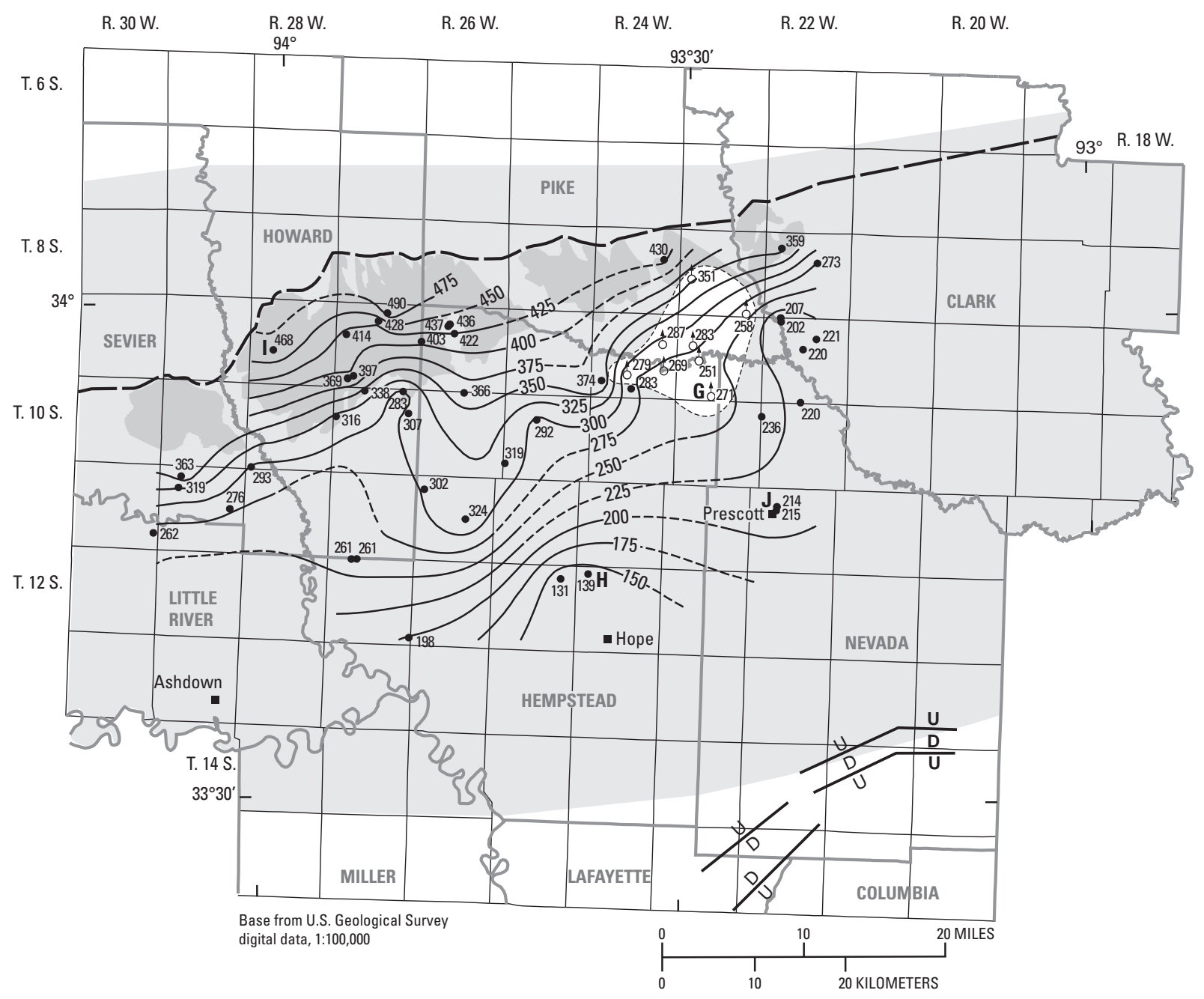

EXPLANATION

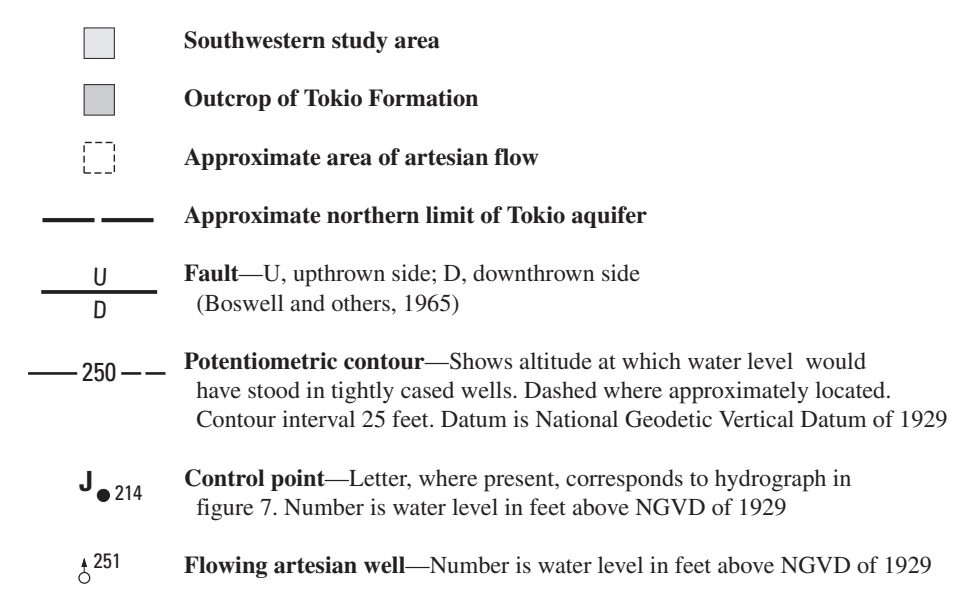

Figure 9. Potentiometric surface of the Tokio aquifer, southwestern Arkansas, February 2005. 
Table 2. Water-level data collected during February 2005 from wells completed in the Tokio aquifer.

[NGVD of 1929, National Geodetic Vertical Datum of 1929—a geodetic datum derived from a general adjustment of the first-order level nets of the United States and Canada, formerly called Sea Level Datum of 1929; Horizontal Datum is North American Datum of 1983; a negative depth to water indicates a flowing artesian well]

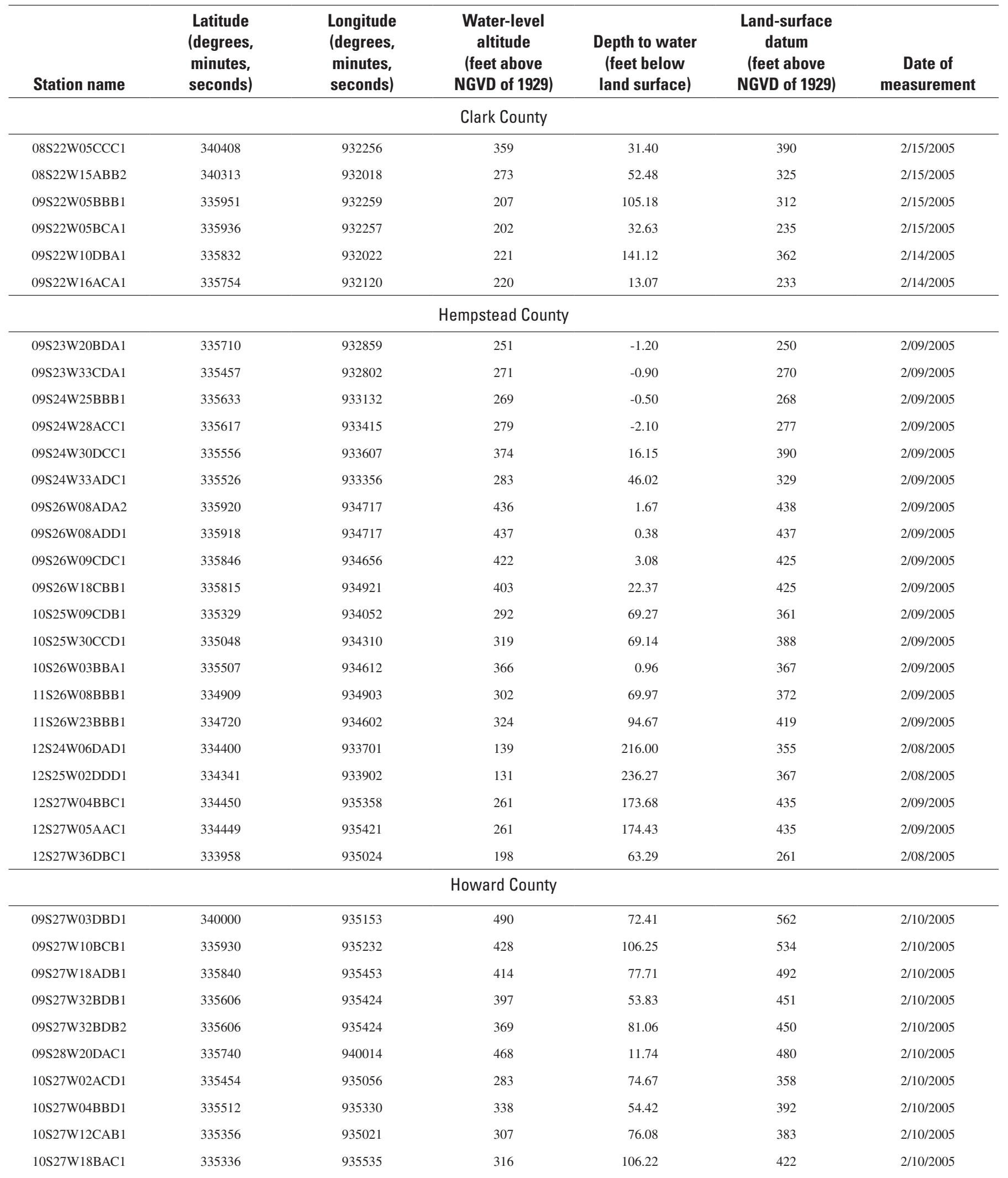


Table 2. Water-level data collected during February 2005 from wells completed in the Tokio aquifer-Continued

[NGVD of 1929, National Geodetic Vertical Datum of 1929—a geodetic datum derived from a general adjustment of the first-order level nets of the United States and Canada, formerly called Sea Level Datum of 1929; Horizontal Datum is North American Datum of 1983; a negative depth to water indicates a flowing artesian well]

\begin{tabular}{|c|c|c|c|c|c|c|}
\hline Station name & $\begin{array}{c}\text { Latitude } \\
\text { (degrees, } \\
\text { minutes, } \\
\text { seconds) }\end{array}$ & $\begin{array}{c}\text { Longitude } \\
\text { (degrees, } \\
\text { minutes, } \\
\text { seconds) }\end{array}$ & $\begin{array}{c}\text { Water-level } \\
\text { altitude } \\
\text { (feet above } \\
\text { NGVD of 1929) }\end{array}$ & $\begin{array}{l}\text { Depth to water } \\
\text { (feet below } \\
\text { land surface) }\end{array}$ & $\begin{array}{c}\text { Land-surface } \\
\text { datum } \\
\text { (feet above } \\
\text { NGVD of 1929) }\end{array}$ & $\begin{array}{c}\text { Date of } \\
\text { measurement }\end{array}$ \\
\hline \multicolumn{7}{|c|}{ Little River County } \\
\hline 11S30W25DDC1 & 334618 & 940852 & 262 & 22.75 & 285 & $2 / 07 / 2005$ \\
\hline 09S22W33DCC1 & 335437 & 932130 & 220 & 5.19 & 225 & $2 / 14 / 2005$ \\
\hline $10 \mathrm{~S} 23 \mathrm{~W} 12 \mathrm{AAA} 1$ & 335345 & 932421 & 236 & 19.64 & 256 & $2 / 14 / 2005$ \\
\hline 11S22W08DAC1 & 334758 & 932315 & 214 & 90.57 & 305 & $2 / 14 / 2005$ \\
\hline 11S22W08DAC8 & 334757 & 932312 & 215 & 90.09 & 305 & $2 / 14 / 2005$ \\
\hline \multicolumn{7}{|c|}{ Pike County } \\
\hline 08S24W14AAC1 & 340324 & 933134 & 430 & 92.61 & 523 & $2 / 10 / 2005$ \\
\hline 09S23W17BBC2 & 335804 & 932925 & 283 & -2.85 & 280 & $2 / 10 / 2005$ \\
\hline 09S24W14AAD1 & 335810 & 933139 & 287 & -1.60 & 285 & $2 / 10 / 2005$ \\
\hline \multicolumn{7}{|c|}{ Sevier County } \\
\hline 10S28W31DCC1 & 335026 & 940145 & 293 & 37.38 & 330 & $2 / 07 / 2005$ \\
\hline 11S29W05DCA1 & 334949 & 940653 & 363 & 116.93 & 480 & $2 / 07 / 2005$ \\
\hline 11S29W08DBB1 & 334907 & 940704 & 319 & 145.91 & 465 & $2 / 07 / 2005$ \\
\hline 11S29W13CCD1 & 334750 & 940317 & 276 & 84.11 & 360 & $2 / 07 / 2005$ \\
\hline
\end{tabular}

by 125 percent and 201 percent, respectively, from 1965 to 1980 and decreased by 93 percent and 80 percent, respectively, from 1980 to 2000 .

The direction of ground-water flow in the northeastern study area of the Nacatoch aquifer generally is towards the southeast. The potentiometric high is located along the north and northwestern boundary of this area. The potentiometric low is located in eastern Greene County.

The direction of ground-water flow in the southwestern study area of the Nacatoch aquifer is towards the south-southeast in Little River, Miller, and Hempstead Counties and to the east-southeast in Nevada and Clark Counties. The potentiometric high is located in the outcrop area in north-central Hempstead County. A cone of depression exists at Hope in Hempstead County. A small depression exists in southern Clark County.

In the northeastern study area of the Nacatoch aquifer, water levels in four wells declined during a period of increased withdrawals from the Nacatoch aquifer. Water levels in two of these wells has an annual decline of about $1.2 \mathrm{ft} / \mathrm{yr}$.
Water withdrawn from the Nacatoch aquifer in Greene and Clay Counties was estimated to be $0.25 \mathrm{Mgal} / \mathrm{d}$ in 1965 and increased to $2.21 \mathrm{Mgal} / \mathrm{d}$ in 1990, an increase of 784 percent during a 25 -year period.

In the southwestern study area of the Nacatoch aquifer, water withdrawn was estimated to be $2.11 \mathrm{Mgal} / \mathrm{d}$ in 1965 and increased by 125 percent to $4.75 \mathrm{Mgal} / \mathrm{d}$ in 1980 . Water withdrawals were estimated to be $0.32 \mathrm{Mgal} / \mathrm{d}$ in 2000 , a decrease of 93 percent from 1980. The sharp decrease in withdrawal rates is explained by public supplies in the southwestern study area converting to surface water and relying less on groundwater sources. Four wells with historical water-level measurements are located in the southwestern study area. Three of the hydrographs show an association between water-level changes in the Nacatoch aquifer and withdrawals. One hydrograph shows no apparent association between water-level changes in the Nacatoch aquifer and withdrawals. The variation in water levels in this well could result from differences in localized withdrawals, climatic variations, or leakage of water from overlying and underlying rock units. 


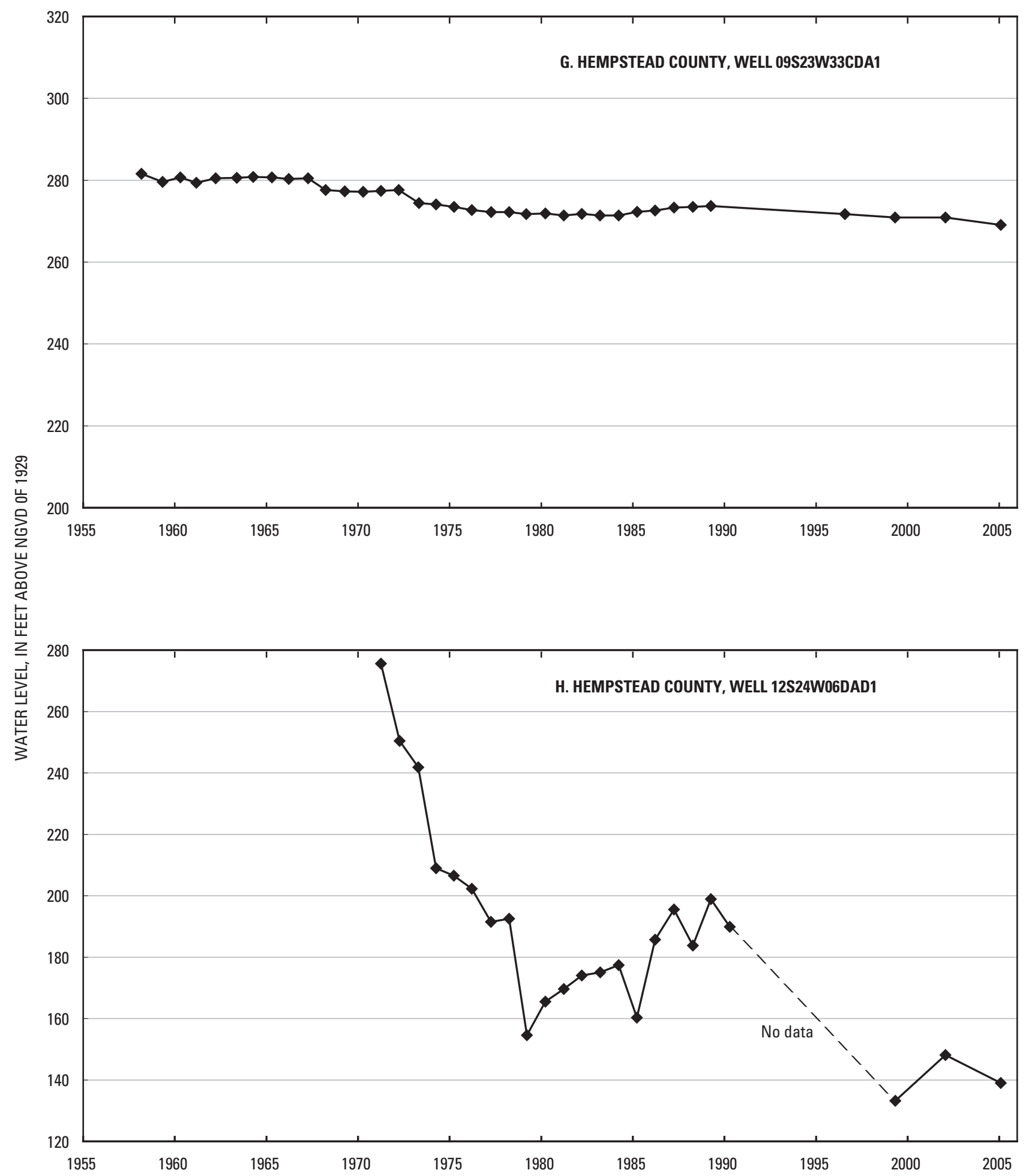

Figure 10. Water level for selected wells completed in the Tokia aquifer. 


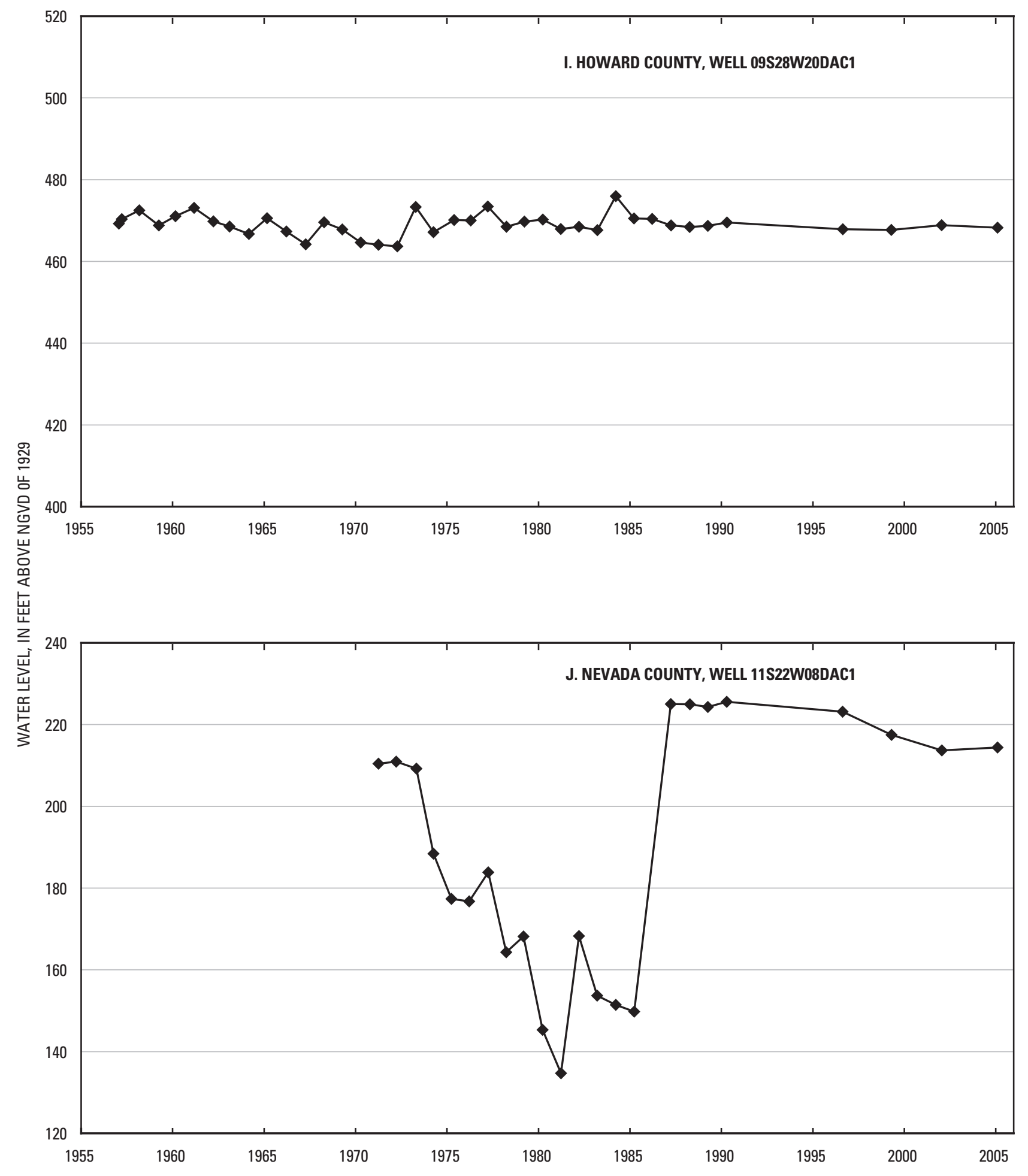

Figure 10. Water level for selected wells completed in the Tokia aquifer-Continued 
The direction of ground-water flow in the Tokio aquifer generally is towards the south or southeast. The potentiometric high is located where the aquifer outcrops in the northwestern part of the study area. An area of artesian flow exists in southeastern Pike, northeastern Hempstead, and northwestern Nevada Counties. A cone of depression may exist about 5 miles northwest of Hope in Hempstead County.

The hydrographs of two of four wells completed in the Tokio aquifer showed a decline and a rise in water levels during a period of increased, then decreased withdrawals from the aquifer in Nevada County. Estimates of withdrawals from the Tokio aquifer increased from $2.0 \mathrm{Mgal} / \mathrm{d}$ in 1965 to 6.02 $\mathrm{Mgal} / \mathrm{d}$ in 1980. Withdrawals from the Tokio aquifer was estimated to be $1.17 \mathrm{Mgal} / \mathrm{d}$ in 2000, a decrease of 80 percent from 1980. Two hydrographs show no apparent association between water-level changes in wells completed in the Tokio aquifer and withdrawals. The variation in water levels in these wells could result from differences in withdrawals, climatic variations, or leakage of water from overlying and underlying rock units.

\section{Selected References}

Boswell, E.H., Moore, G.K., MacCary, L.M., and others, 1965, Cretaceous aquifers in the Mississippi Embayment: U.S. Geological Survey Professional Paper 448-C, 37 p.

Counts, H.B., Tait, D.B., Klein, Howard, and Billingsley, G.A., 1955, Ground-water resources in a part of southwestern Arkansas: U.S. Geological Survey Water Resources Circular No. 2, 35 p.

Fenneman, N.M., 1931, Physiography of western United States: New York, McGraw-Hill Book Co., Inc., 689 p.

Halberg, H.N., 1972, Use of water in Arkansas, 1970: Arkansas Geological Commission Water Resources Summary Number 7, 17 p.

Halberg, H.N., 1977, Use of water in Arkansas, 1975: Arkansas Geological Commission Water Resources Summary Number 9, 28 p.
Halberg, H.N. and Stephens, J.W., 1966, Use of water in Arkansas, 1965: Arkansas Geological Commission Water Resources Summary Number 5, 12 p.

Holland, T.W., 2004, Estimated water use in Arkansas, 2000: U.S. Geological Survey Scientific Investigations Report 2004-5230, $31 \mathrm{p}$.

Holland, T.W., 1999, Water use in Arkansas, 1995: U.S. Geological Survey Open-File Report 99-188, 1 sheet.

Holland, T.W., 1993, Use of water in Arkansas, 1990: U.S. Geological Survey Open-File Report 93-48, pamphlet.

Holland, T.W., 1987, Use of water in Arkansas, 1985: Arkansas Geological Commission Water Resources Summary Number 14, $30 \mathrm{p}$.

Holland, T.W., and Ludwig, A.H., 1981, Use of water in Arkansas, 1980: Arkansas Geological Commission Water Resources Summary Number 14, 30 p.

Ludwig, A.H., 1972, Water resources of Hempstead, Lafayette, Little River, Miller, and Nevada Counties, Arkansas: U.S. Geological Survey Water-Supply Paper 1998, 41 p.

Payne, J.N., 1968, Hydrologic significance of the lithofacies of the Sparta Sand in Arkansas, Louisiana, Mississippi, and Texas: U.S. Geological Survey Professional Paper 569-A, $17 \mathrm{p}$.

Petersen, J.C., Broom, M.E., and Bush, W.V., 1985, Geohydrologic units of the Gulf Coastal Plain in Arkansas: U.S. Geological Survey Water-Resources Investigations Report 85-4116, 20 p.

Plebuch, R.O., and Hines, M.S., 1969, Water resources of Clark, Cleveland, and Dallas Counties, Arkansas: U.S. Geological Survey Water-Supply Paper 1879-A, 32 p.

Schrader. T.P., and Scheiderer, Rheannon M., 2004, Status of water levels in aquifers in the Nacatoch Sand of southwestern and northeastern Arkansas and Tokio Formation of southwestern Arkansas, 2002: U.S. Geological Survey Water-Resources Investigations Report 03-4284, 24 p. 
For more information concerning the research described in this report, contact:

U.S. Geological Survey

Arkansas Water Science Center

401 Hardin Road

Little Rock, AR 72211-3528

(501) 228-3600

http://ar.water.usgs.gov 



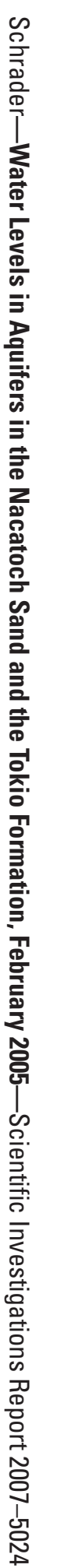

8 Printed on recycled paper 